\title{
¡MENUDO GUIRIGAY! PRENSA Y PODER POLÍTICO EN MADRID DURANTE EL RÉGIMEN CONSTITUCIONAL DE 1837
}

\section{¡MENUDO GUIRIGAY! PRESS AND POLITICAL POWER IN MADRID DURING THE CONSTITUTIONAL REGIME OF 1837}

\author{
Javier Pérez Núñez \\ Universidad Autónoma de Madrid
}

\begin{abstract}
SUMARIO: I. LA LIBERTAD DE PRENSA BAJO LA CONSTITUCIÓN DE 1837: LEGISLACIÓN BÁSICA.- II. A LOS PROGRESISTAS LES SUPERA LA OPOSICIÓN DE LA PRENSA.- III LOS MODERADOS REPRUEBAN EL JUICIO POR JURADOS.IV CASI TODOS CONTRA BALDOMERO ESPARTERO: LA FORMACIÓN DE LA COALICIÓN DE LA PRENSA. - EPÍLOGO: HACIA LA SUPRESIÓN DEL JURADO.
\end{abstract}

Resumen: Estudio sobre el ejercicio de la libertad de prensa en Madrid durante el régimen constitucional de 1837, regulado por el sistema de juicio por jurados. En primer término, observa su aplicación durante la regencia de María Cristina y constata las diferencias y discrepancias que sobre el mismo tienen los progresistas y moderados, que se suceden en el poder. En segundo término, estudia la formación de la coalición de la prensa que se produjo en Madrid durante la regencia de Baldomero Espartero. Y, por último, analiza la supresión del sistema del juicio por jurados a partir de las propuestas de los conservadores.

\begin{abstract}
Study about the practice of press freedom in Madrid during the constitutional regime of 1837, regulated by the jury trial system. First, it observes its application during Maria Cristina's regency and notes the differences and discrepancies on its practice among the progressive and moderate, who are succeeded in power. Secondly, it studies the formation of press coalition that took place in Madrid during Baldomero Espartero's regency. And, finally, it analyzes the jury trial system suppression from the proposals of the conservatives.
\end{abstract}

Palabras clave: Historia política, Liberalismo español, Prensa, Madrid, Régimen constitucional de 1837.

Key Words: Political history, Spanish liberalism, Press, Madrid, Constitutional regime of 1837

En el Diccionario de la Lengua Española de la Real Academia Española $\left(23^{a}\right.$ ed.) se define guirigay como "gritería y confusión que resulta cuando varios hablan a la vez o cantan desordenadamente". Este trabajo es la expresión de algo de esto, de la bulla y el desbarajuste provocados por el elevado número de periódicos de tendencias opuestas publicados a la vez en Madrid. De ahí que antepongamos el término guirigay en el título. Y es que fue durante el tiempo de 
la Constitución de 1837, en la época de las Regencias de María Cristina y Baldomero Espartero, en que imperaba un régimen de libertad de prensa regulado por el sistema de juicio por jurados, cuando se vivió una auténtica batalla campal entre una infinitud de diarios de todo el abanico ideológico y los gobiernos de distinto signo político. Aquellos, además de informar, intentaban zaherir y denigrar a los ejecutivos, si no eran de su simpatía, y éstos utilizaban a las publicaciones oficiales y afines para afirmar su pensamiento y, mediante medios fundamentalmente coactivos, pretendian silenciar a las críticas de la oposición. Entre ambos, no siempre cumpliendo un papel arbitral, se encontrarian los jurados.

Este arduo enfrentamiento, sobre el que se profundiza en las siguientes páginas, tenía una cabecera de periódico que lo ejemplificaba y en la que también se encuentra la razón del título de este trabajo, El Guirigay. Este periódico, que salió a la luz a comienzos de 1839, tenía por bandera la visión más avanzada del régimen constitucional de 1837, la doceañista democrática. Pero sus redactores, entre los que se encontraban los abogados Juan Bautista Alonso y Luis González Bravo (sí, el que cinco años después se presentaría como uno de los adalides del reaccionarismo, entonces era radical), la enarbolaban de manera muy demagógica y populista y, más que satírica -como ellos decían-, de forma muy provocativa e insultante. La permanente denigración de la regente y de los ministros, así como la propagación de doctrinas democráticas que realizaba en sus páginas, sacó de sus casillas al Gobierno conservador del momento. Pero, más aún, que lo hiciera con el beneplácito del jurado y por eso perdió los estribos y acabó suspendiendo la publicación, a la vez que intentó con escaso éxito recuperar la censura previa.

Durante la regencia de María Cristina hubo otros periódicos similares a $\mathrm{El}$ Guirigay, como en 1836-1837 el conservador El Duende Liberal o el coetáneo, también radical, El Diablo Suelto. Más o menos en esta línea sarcástica e impertinente se situarian El Hablador, que se imprimió durante un año desde de julio de 1837 o El Graduador, que solo pudo publicar seis números en abril de 1838. Pero, cuando verdaderamente creció este tipo de prensa, fue durante el trienio esparterista. Entonces fue cuando los lectores, de la mano del periódico republicano la Guindilla, publicado entre $1842-1843$ y dirigido Wenceslao Ayguals de Izco, se familiarizaron con las caricaturas y motes a los políticos. Sin embargo, fue en espectro conservador donde más florecieron este tipo de diarios sarcásticopolítico-burlescos: primero, entre 1840-1841, fue El Trueno; después, los dirigidos por Manuel Antonio de las Heras (compañero de Luis Bravo Murillo en El Guirigay), en 1841 El Cangrejo y entre 1841-1846 La Posdata.

No están todos los diarios de esta índole porque, con la salvedad principalmente de este último, su vida fue muy efimera. Enseguida fueron perseguidos por las autoridades gubernativas y judiciales $y$ acabaron sucumbiendo. Pero que aparecieran este tipo de diarios eran la expresión del nuevo marco de libertad de imprenta: primero, porque estos escritos, por muy fastidiosos que fueran dentro de unos márgenes, podian publicarse, aunque fuera momentáneamente; $\mathrm{y}$, segundo, porque, como ocurría con el paralelo régimen representativo que lo integraba y de la misma manera que su clase política, la prensa y los periodistas necesitaban adiestramiento y práctica. La libertad de prensa, como la libertad en general, se aprende con su uso. 
Pues bien, una de las cosas que hace este trabajo es observar el desarrollo de estos periódicos. Pero también el de los otros, de los más adelantados, los más profesionales, que los hubo, bastantes y de todos los colores políticos. El primero, el más veterano, y nuestro juicio el más aventajado, fue el diario progresista Eco del Comercio que, dirigido en una primera etapa por el diputado radical Fermín Caballero, se publicó entre 1834-1849. Rivalizaron y debatieron con él dos importantes diarios que se sucedieron en el tiempo: El Correo Nacional, periódico dirigido por Andrés Borrego que, contando con la colaboración de afamadas plumas del moderantismo, estuvo en la calle entre 1838-1842; y El Heraldo que, publicado entre 1842-1854, en su primera época fue dirigido por el político conservador Luis Sartorius. Periódicos dignos de estos contrincantes fueron $E l$ Espectador, diario liberal impreso entre 1841-1848 que tuvo una primera etapa de gran fervor esparterista, y El Huracán, diario republicano que sucedió a $L a$ Revolución y se publicó entre 1841-1843, teniendo como director al egregio Patricio Olavarría.

Éstos periódicos, los anteriores y muchos más aparecen en las páginas de este artículo, que se centra en el estudio de las relaciones entre la prensa y poder político durante el régimen constitucional de 1837. Observa su articulación en un régimen de libertad de imprenta que, teniendo sus antecedentes en el trienio liberal, fue durante ese momento cuando alcanza su pleno desarrollo. Por eso, lo que antecede al desarrollo histórico es una aproximación al marco legislativo fundamental. A partir de aquí, seguidamente, vemos su aplicación desde el poder, primero, por los progresistas y, después, por los moderados, examinando las dificultades con las que se enfrentan y las discrepancias y diferente apreciación que tienen del ejercicio de la libertad de imprenta y de su regulación. A continuación, abordamos el trienio liderado por Baldomero Espartero y fijamos principalmente nuestra atención en la formación de la coalición periodística que, abarcando a todo el abanico ideológico, se establece contra él y sus gobiernos. Por último, observamos cómo esta alianza de la prensa es clave para articulación de una coalición antiesparterista de amplio espectro, que se lleva por delante, además de a esta etapa política, al propio régimen constitucional de 1837, y constatamos como la salida política de éste se realiza a través de la puesta en vigor de los proyectos legislativos (incluido el de libertad de imprenta) que, bajo su marco habian propuesto los moderados, pero que se acomodan mejor a un modelo constitucional más conservador, como el de $1845^{1}$.

\section{LA LIBERTAD DE PRENSA BAJO LA CONSTITUCIÓN DE 1837: LEGISLACIÓN BÁSICA.}

La revolución del verano de 1836 tuvo como propósito principal la instauración de un sistema político auténticamente representativo que, fundado en la soberanía nacional, superara el restringido del Estatuto Real, que tenía en

1 Este artículo se ha realizado en el marco del proyecto de investigación "Intercambios culturales y creación de identidades a través de la literatura, ss. XIX y XX" (HAR2016-76398-P). $\mathrm{Su}$ primera parte, la de la regencia de María Cristina, es parcialmente deudora de algunos aspectos recogidos en dos artículos que publicamos con anterioridad: "El gobierno politico de Madrid durante la última experiencia de la Constitución de 1812 (1836-1837)", Historia Constitucional, no 12, 2011, pp. 111-160; y "Gobernar Madrid bajo el régimen constitucional de 1837. Regencia de María Cristina”, Anuario de Historia del Derecho Español, n 84, 2014, pp. 445579. La segunda parte, la más amplia del trabajo, es totalmente inédita. 
la Corona la instancia decisoria. Como la libertad de imprimir y publicar es un derecho imprescindible para todo régimen representativo, se debía poner fin al sistema tradicional de censura previa hasta entonces vigente. Por eso el replanteamiento de la Constitución de 1812, aunque fuera de forma transitoria para proceder a su reforma, estuvo acompañado de la recuperación de la normativa de imprenta del trienio liberal, fundada en "el derecho conferido a todo español a imprimir y publicar sus pensamientos sin necesidad de censura previa".

A partir de este principio inexcusable, la reglamentación restaurada, ordenada principalmente por las leyes del trienio liberal de 22 de octubre de 1820 y 12 de febrero de 1822, suponía que el Gobierno y sus delegados (los jefes políticos) ante todo tuviesen la obligación de proteger a los ciudadanos en el ejercicio de este derecho. De ahí que, para garantizarlo mejor, se recogieran los limites pormenorizando los abusos punibles y se instituyera el jurado popular como el tribunal más idóneo para juzgarlos.

Los abusos estaban graduados con las penas correspondientes (de seis años a seis meses de prisión) en cinco calificaciones de acuerdo con lo recogido en los escritos: subversivos eran considerados los que conspiraran para trastornar o destruir la religión o la Constitución del Estado o injuriaran al rey; sediciosos eran los que recogieran máximas o doctrinas dirigidas a excitar la rebelión o la perturbación de la tranquilidad pública; incitadores a la desobediencia se tildaban los que impelieran a la desobediencia de las leyes o de las autoridades mediante sátiras o invectivas; obscenos eran aquellos que se considerara ofendieran a la moral o la decencia pública; e injuriosos eran conceptuados los que atacaran la reputación o el honor de los particulares. La responsabilidad contraida por estas infracciones recaía en el autor o editor de lo publicado, que era denunciado, principalmente, a instancias del gobierno o de sus delegados, por los promotores fiscales nombrados por las diputaciones provinciales.

Desde este momento empezaba a funcionar el jurado. El primer paso para su formación era el nombramiento anual de los llamados jueces de hecho entre los ciudadanos activos residentes en la capital por parte de su ayuntamiento y de la diputación. De ellos, ante una denuncia, el alcalde de la capital, mediante sorteo, elegía a los nueve miembros del jurado de la acusación, que era el que declaraba si había o no lugar a la formación de causa. Si el dictamen era afirmativo, abría el proceso con la suspensión cautelar de la venta del escrito y la exigencia de fianza o detención, según el caso, del sujeto responsable. Acto seguido, el citado alcalde volvía a elegir también por sorteo a los doce miembros del jurado llamado de calificación. Recibía este nombre porque en el juicio celebrado a puerta abierta, permitiéndose intervenciones para defender al acusado o sostener la denuncia, debía calificar el escrito, en el caso de convenir la existencia de abuso conforme a los criterios señalados, quedando al juez el señalamiento de la pena correspondiente ${ }^{2}$.

\footnotetext{
2 Esta legislación sobre la libertad de imprenta la hemos interpretado siguiendo a: Mercedes Cabrera, Antonio Elorza, Javier Valero y Matilde Vázquez, "Datos para el estudio cuantitativo de la prensa (1850-1875)", en Manuel Tuñón de Lara, Prensa y sociedad en España, 1820-1936, Edicusa, Madrid, 1975 pp. 54-56; Alicia Fiestas Loza, "La libertad de imprenta en las dos primeras etapas del liberalismo español”, Anuario de Historia del Derecho Español, n 59, 1989, pp. 422-458; y Juan Ignacio Marcuello Benedicto, "La libertad de imprenta y su marco legal en la España liberal", Ayer, n 34, 1999, pp. 68-71.
} 
A esta reglamentación indicada a garantizar mejor el derecho a imprimir y publicar libremente, se sumó la nueva orientación conferida a la prensa oficial, la Gaceta de Madrid y los Boletines Oficiales de las provincias (y en la capital el Diario de Madrid). Pierden el carácter que había dominado en ellos durante el régimen del Estatuto de medios de difusión del ideario del partido gobernante, para convertirse paulatinamente en instrumentos de protección legal de los ciudadanos y de sus derechos. Este es sentido que tuvieron las mejoras introducidas en la redacción de la Gaceta el 2 de junio de 1837, que después fueron trasladadas a los Boletines provinciales. Se asentaban, dando primacía a todo lo demás, otorgando la máxima celeridad y más escrupulosa exactitud y no omitiendo mandato superior alguno, en la publicación de la legislación integra del Estado, transformándose así -se subrayaba- en Boletín oficial nacional. Por eso, para que pudiera ser efectivo este importante paso para la afirmación y nacionalización jurídico-política del Estado de Derecho, se estableció la suscripción obligatoria de la publicación oficial para todas las dependencias del Ministerio de la Gobernación, las jefaturas politicas, las diputaciones provinciales y, cuando menos, los ayuntamientos cabezas de partido judicial. Además, en la Gaceta remodelada se insertarian las sesiones de las Cortes, con toda la extensión que fuera posible y "sin preferencias de ninguna especie y sin color político" (como había ocurrido en el tiempo del Estatuto Real) y las noticias oficiales, en las que "la verdad y el comedimiento debían ser el carácter distintivo". En la parte no oficial, tal como ocurriera en los anteriores Diarios de la Administración y Anales Administrativos, se publicarian de manera selectiva los adelantamientos en las ciencias y las artes, la industria y el comercio ${ }^{3}$.

El ejercicio de la libertad de prensa bajo la normativa retomada por el Gobierno progresista de José Maria Calatrava, que había asumido las riendas del Estado después de la revolución de 1836, produjo fundamentalmente dos extralimitaciones. Por un lado, la situación de impunidad en la que quedaban los diarios con medios económicos, principalmente los conservadores, al aparecer como firmantes de los artículos sancionados presos o indigentes retribuidos de distintas maneras. Por otro lado, la proliferación de una prensa popular que, mitificando la Constitución de 1812 y oponiéndose a su reforma, iba desvelando un incipiente ideario demócrata-republicano. Como estos planteamientos eran contrarios al abandono casi total de este Código y a la reorientación doctrinaria del nuevo texto constitucional asumidos por el progresismo más contenido dominante en ese Gobierno y en las Cortes Constituyentes, un grupo de diputados (entre los que se encontraban los principales miembros del Ministerio) solicitó que se adoptaran las medidas urgentes que permitieran conciliar "la libertad de prensa con la seguridad del Estado".

La respuesta de la asamblea parlamentaria, realizando un paréntesis en su labor constitucional, quedó plasmada en la ley de 22 de marzo de 1837 . En ella lo primero que se hacia era definir un periódico: "se entenderá por periódico -se subrayaba- todo impreso que se publique en plazos determinados o inciertos, siempre que sea bajo un título adoptado previamente, y que no exceda de seis pliegos de impresión". Seguidamente, se establecía que eran necesarias para la

3 Archivo Histórico Nacional (en adelante, A.H.N.), Consejos, 11.324/1; y Marta Lorente Sariñena, La voz del Estado. La publicación de las normas (1810-1889), Madrid, Boletín Oficial del Estado/Centro de Estudios Políticos y Constitucionales, 2001, pp. 78-94. 
publicación de un diario no oficial y que tratara de materias religiosas o políticas dos figuras contempladas en la ordenación de imprenta del tiempo del Estatuto e importadas de la legislación francesa: el editor responsable, que debía ser un ciudadano en ejercicio de sus derechos y avecindado en el municipio de publicación del periódico; y el depósito, que iba desde 40.000 reales en Madrid hasta 10.000 reales en las localidades menores. De esta forma, se pretendia garantizar que el contenido de la publicación se ajustara a lo permitido por la legislación de prensa, ya que, en caso de transgresión, el primero asumía de manera subsidiaria la responsabilidad que correspondia al autor y el segundo cubría las penas pecuniarias por los abusos y las costas del proceso. En los folletos u hojas sueltas el lugar del editor lo ocupaba el impresor y, en su defecto, el vendedor.

Esta restricción del ejercicio de la libertad de imprenta a las clases pudientes se encuentra en linea con la obra de la asamblea constituyente. La Constitución transaccional de 18 de junio de 1837 no sólo acogía del doctrinarismo francés el principio y la práctica política de la soberanía compartida y el bicameralismo, sino que, además de relegar el principio de la soberanía nacional al preámbulo como una simple proclama doctrinal, hacia una lectura liberal individualista y contenida de los derechos individuales básicos reconocidos, convirtiendo a la propiedad en el distintivo de capacitación para el ejercicio de los derechos políticos.

Así, al igual que el derecho a la participación política regulado por la ley de 20 de julio era reconducido censitariamente, otro tanto ocurría con el reconocimiento constitucional a todo español del derecho a imprimir y publicar libremente sus ideas sin previa censura, al tener que ejercerse con sujeción a las leyes. Éstas eran principalmente la citada norma del 22 de marzo y la ley de imprenta 17 de octubre que, en línea con la anterior electoral, incidía en reservar el derecho a los propietarios. A partir de entonces no bastaba con depositar una fianza para ser editor responsable, era necesario, además, ya que por primera vez se hacia responsable de todo cuanto se publicara en el periódico a su cargo, acreditar la calidad de "contribuyentes por contribuciones directas" (que, para Madrid, se situaba en 400 reales). Del mismo modo esta condición censitaria incrementada se hacia extensiva para los jueces de hecho (los de la capital debian justificar 500 reales también de contribución directa).

Pero la restricción de la actividad y el control de la prensa a las clases acomodadas no eran suficientes. Por eso, consolidando el terreno ganado en sentido retrógrado por la anterior ley, la de 17 de octubre, primero, facultaba también a las Cortes (a los dos cuerpos colegisladores) para conocer y juzgar "los abusos contra la libertad de imprenta", calificando a los escritos que las atacaran o desacreditaran de subversivos. Segundo, sustituía a los promotores fiscales nombrados por las diputaciones provinciales por los existentes en los tribunales de primera instancia. Y, tercero, establecia que la expendición de cualquier periódico comenzaría, "necesariamente y bajo la multa de 500 reales de no hacerlo", con la entrega de un ejemplar, entre otros, al jefe politico; y, al tiempo, se facultaba a éste y al Gobierno para suspender y asegurar el depósito de ejemplares de un periódico cuando a su juicio se pusiese en peligro la tranquilidad pública, eso sí, debía ser denunciado en el plazo de 12 horas y dictaminado por el jurado de la acusación en el de 48 horas. En definitiva, se incrementaba el control gubernativo sobre la prensa y, con las figuras reseñadas, 
del depósito previo de ejemplares y del llamado derecho de recogida, se corría el peligro de reintroducir subrepticiamente el mecanismo preventivo de la censura. Frente a esta amenaza, serian los jurados, como veremos, la gran salvaguarda del ejercicio de libertad de prensa ${ }^{4}$.

\section{A LOS PROGRESISTAS LES SUPERA LA OPOSICIÓN DE LA PRENSA.}

La recuperación del régimen de la libertad de imprenta, atendiendo a una de las principales demandas del movimiento insurreccional del verano de 1836, en Madrid estuvo acompañada de un importante retroceso de la prensa de tendencia conservadora. Así, desaparecieron las cabeceras de los diarios más comprometidos con la anterior situación como la Ley, la Revista-Mensajero o El Jorobado. Se mantuvieron algunos periódicos combativos como El Mundo, diario del pueblo, que tenía a Santos López Pelegrín como director y a Mariano José de Larra como redactor, El Castellano, periódico de politica, administración y comercio, dirigido por el diputado Aniceto Álvaro, y, el recién creado y más díscolo, El Duende Liberal. Además, junto a ellos, contando con una cierta trayectoria y una posición más centrada, estaba El Español.

Definiendo principalmente el discurso ideológico y politico del liberalismo progresista se encontraba el rotativo más importante del momento, el Eco del Comercio, dirigido por del diputado Fermín Caballero. Se situaba en este mismo espectro El Patriota que, contando con Mariano Barrio como editor en representación de una asociación de comerciantes y propietarios de la capital, engulliría a la Revista Nacional, continuadora del periódico mendizabalista El Nacional, y patrocinaría la edición de dos publicaciones de corta duración como El Mata-Moscas y El Amigo del pueblo. Una vida igual de efimera tendrian los diarios de signo más radical surgidos con el cambio político, como, entre otros, $E l$ Ladrón, La Flecha, El Ciudadano, El Tribuno o El Acicate ${ }^{5}$.

Los periodistas de estos rotativos tardaron poco en adaptarse a escribir sin el rigor de la censura previa y la libertad de prensa muy pronto devino en un desbordamiento y extralimitación de las opiniones, particularmente de aquellos que se situaban en la oposición al progresismo dominante. Así parece, ya que no se trataba de una crítica, una censura o disconformidad con las disposiciones del Gobierno, con la actuación de la administración o con la labor de las Cortes, sino

4 Para la legislación de imprenta de las Cortes Constituyentes: Demetrio Castro Alfín, Los males de la imprenta. Politica y libertad de prensa en una sociedad dual, Madrid, Centro de Investigaciones Sociológicas, 1998, pp. 39-40; Juan Ignacio Marcuello Benedicto, "La libertad de imprenta y su marco legal en la España liberal”, op. cit., pp. 72-75; José A. Pérez Juan, "La aplicación de la ley de imprenta de 15 de marzo de 1837", Anuario de Historia del Derecho Español, $\mathrm{n}^{\circ}$ 76, 2006, pp. 667-690; y José Manuel Romero Moreno, Proceso y derechos en la España del siglo XIX, Madrid, Centro Estudios Constitucionales, 1983, pp.184-185 y 195.

5 Para el sucinto panorama de la prensa madrileña: Pedro Gómez Aparicio, Historia del periodismo español, vol. 1: Desde la "Gaceta de Madrid" hasta el destronamiento de Isabel II, Madrid, Editora Nacional, 1967, pp. 229-241; Eugenio Hartzenbusch, Apuntes para un catálogo de periódicos madrileños desde el año de 1661 a 1870, Madrid, Establecimiento tipográfico de "Sucesores de Rivadeneyra", 1894 (Edición facsímil: Madrid, Biblioteca Nacional-Ollero y Ramos, 1993), pp. 44-53; Robert Marrast, José Espronceda y su tiempo, Barcelona, Crítica, 1989, pp. 550-552; y y Maria Cruz Seoane y María Dolores Saiz, Historia del periodismo en España. 2. El siglo XIX, Madrid, Alianza, Editorial, 1996, pp. 152-154 y 176-179. 
de la publicación de noticias falsas e infundadas y de comentarios infamantes e insultantes, así como incitaciones al desorden y a la insubordinación.

Para hacer frente a estos posibles abusos estaba el jurado formado por los llamados jueces de hecho, que en Madrid alcanzando la cifra de 103 los nombraron la Diputación madrileña y el Ayuntamiento de la capital. Perteneciendo la mayoria al liberalismo gobernante, teniendo por ello muchos de ellos que ser reemplazados al resultar seleccionados o elegidos miembros de las instituciones administrativas y la legislativas renovadas, para el comienzo de septiembre ya empezaron a funcionar como jurado de la acusación y de octubre de la calificación. Pues bien, las denuncias efectuadas hasta finales de marzo, cuando entró en vigor la nueva regulación sobre la imprenta, señalaban a los periódicos conservadores y radicales como los principales artífices de los despropósitos significados: 29 y 13 artículos imputados, respectivamente, frente a 11 de la prensa progresista lo expresan. Y lo confirmaban las decisiones de los jurados, declarando la formación de causa a 19 de los primeros (5 son de $E l$ Duende Liberal), a la totalidad de los segundos (6 son de El Tribuno) y sólo 6 de los terceros ${ }^{6}$.

No conocemos los fallos de todas estas causas, pero sí sabemos que entre los firmantes de los artículos sancionados se encontraban presos e indigentes, que lo hacían a veces a cambio de un simple "vaso de vino". Para el Gobierno de José María Calatrava esta situación de impunidad en que se quedaban los excesos de los diarios con medios económicos era inadmisible, tanto más cuanto en plena guerra civil, profesando alguno de ellos un ideario lindante con el carlista, ridiculizaban y denigraban la labor de las Cortes y de sus diputados. Tampoco para ese ejecutivo era tolerable la proliferación de la prensa popular que, mitificando a la Constitución de 1812 y oponiéndose a su reforma, estaban difundiendo propuestas democráticas y republicanas. Pues bien, para hacer frente a estos extremos, las Cortes, atendiendo a las distintas demandas en ese sentido, aprobaron la ya significada ley de 22 de marzo ${ }^{7}$.

Con esta revisión conservadora del régimen de libertad se estableció un dique económico, que dificultó sobremanera a los sectores radicales la difusión de sus opiniones en publicaciones periódicas. Así la mayoría de los diarios antes citados y alguno más dejaron de existir. Pero también la incapacidad de afrontar las fianzas impidió la continuidad de periódicos de predicamento liberal progresista como le ocurrió a El Constitucional, que había iniciado su andadura al comenzar 1837, o la mencionada Revista Nacional, nacida con el cambio politico. El Hablador, diario político sarcástico con Bartolomé Prato como director y Antonio Granados como editor responsable, vendría a cubrir este espacio, pero con un talante más inclinado al moderantismo. En este espectro conservador, como ya había augurado Agustín Argüelles durante el debate de la reforma, se

6 Para la formación y primeras actuaciones de los jurados en Madrid: A.H.N., Consejos, 11.319/18; Archivo Regional de la Comunidad de Madrid (en adelante, A.R.C.M.), libros de actas de las sesiones de la Diputación provincial, $\mathrm{n}^{\circ}$ 23, sesión 30.08.1836; Archivo de la Villa de Madrid (en adelante, A.V.M.), Secretaría 2/424/18; y Eco del Comercio, 31.08.1836.

\footnotetext{
7 Para los excesos periodísticos: Diario de Sesiones de las Cortes (en adelante, D.S.C.), Cortes Constituyentes, 16.11.1836, 17.02.1837 y 24-28.02.1837, pp. 281-282, 1595-1611 y 1741-2036; y José A. Pérez Juan, "La aplicación de la ley de imprenta de 15 de marzo de 1837", op. cit., pp. 690-697.
} 
contó con nuevas cabeceras, como el diario filocarlista El Eco de la razón y de la justicia, La España, que contó con la pluma de Joaquín Francisco Pacheco, y, sobre todo, El Porvenir, periódico conservador que tenía en el plantel de redactores a Juan Donoso Cortés, Juan Bravo Murillo y Dionisio Alcalá Galiano ${ }^{8}$.

Incrementados los medios de difusión del proyecto e ideario moderado, en la recta final de la redacción de la nueva carta magna se desarrolló un discurso mucho más agresivo contra "el motín de La Granja” y "el partido de la anarquía", la formación progresista, y sus presupuestos fundamentales. Así, impugnaban el principio de la soberanía nacional y que las Cortes fueran su expresión, y cuestionaban su legitimidad y la de su labor constitucional. Paralelamente, realizaban una auténtica apología del "régimen del Estatuto" y de la Corona, a la que presentaban como "la única áncora de salvación" y "la garantía más preciosa de la libertad"9.

Para frenar esta ofensiva de la prensa conservadora no se menospreciaron esfuerzos. En primer lugar, se contó con la colaboración de los medios progresistas, como el Eco del Comercio, y corporaciones del mismo signo politico, como el Ayuntamiento de Madrid, que reprobaron con firmeza esas diatribas. Además, éste con la Diputación provincial siguieron apoyando al ejecutivo en la renovación de los jueces de hecho con afines a su fuerza política liberal. Así, en segundo lugar, los jurados formados con ellos tuvieron un celo particular en hacer prosperar las denuncias de los fiscales: de los 25 artículos denunciados entre abril y agosto, 24 eran de periódicos de orientación conservadora, declarando la formación de causa a 15 de ellos ${ }^{10}$.

En tercer lugar, se recurrió a métodos algo menos amables, particularmente con el diario El Porvenir. En las páginas del ejemplar del 20 de junio se publicó un artículo que, calificado de "altamente subversivo y sedicioso", para el ministro de la Gobernación, Pío Pita Pizarro, había sobrepasado todos los límites admisibles y por eso exigió al jefe político de Madrid "la más estrecha vigilancia y esmerado celo para impedir semejantes escándalos". Éste, Antonio Pinel (marqués de Ceballos), no sólo consiguió que el jurado fallara por unanimidad que había lugar a formación de causa, sino que enalteció tanto los ánimos que "una turba de hombres obcecados" apalearon a su principal editor.

Pues bien, a pesar de que en represalia actos de similares características se reprodujeran contra los responsables del periódico progresista El Patriota, el delegado gubernativo de Madrid se mantuvo impertérrito en su pedagogía correctiva. Así, el 2 de agosto, con el objeto de averiguar el autor de un artículo publicado en El Porvenir, procedió a detener a algunos de sus redactores, encontrándose entre ellos el abogado Juan Bravo Murillo. La prensa de todo el espectro liberal se alzó contra semejante atropello y los detenidos fueron liberados. Con todo, es cierto que el Ministerio de la Gobernación mantuvo esta

8 Eugenio Hartzenbusch, Apuntes para un catálogo de periódicos madrileños desde el año de 1661 a 1870, op. cit., pp. 52-55.

9 A.H.N., Consejos, 11330/19. Eco del Comercio, 16 y 27.03.1837.

10 Para la formación y actuación del jurado de imprenta de Madrid: A.R.C.M., libros de actas de las sesiones de la Diputación provincial, $\mathrm{n}^{\circ}$ 23, sesión 3.04.1837; AVM, Secretaría, libros de acuerdos del Ayuntamiento de Madrid, n 272, sesión 10.04.1837, 2/356/61 y 4/163/6; y Diario de Madrid, 5.05.1837. 
política de acoso contra la prensa conservadora más recalcitrante, pero también que ésta, aprovechando el malestar generado por la expedición del pretendiente carlista, intensificó su campaña de oposición al Gobierno de José María Calatrava. Y si, por un lado, la acción de aquél paulatinamente fue haciendo sucumbir algunas de sus cabeceras: a finales de mayo fue El Duende Liberal, a mediados de julio El Eco de la Razón y de la Justicia y a comienzos de septiembre El Porvenir. Por otro lado, la contribución al enrarecimiento del clima político de éstos y otros diarios de la misma orientación, facilitó el éxito de la sublevación de los oficiales de las fuerzas isabelinas acantonadas en las cercanías de Madrid contra ese ejecutivo, que el 18 de agosto acabó cesando ${ }^{11}$.

Aunque algunos periódicos moderados presentaran esta insubordinación como contrapunto a la de agosto de 1836, al recuperar -subrayaba El Mundo- el libre ejercicio de la prerrogativa regia, "sacándola del poder opresor de los ministros nombrados en la sedición de La Granja", no fue exactamente así. Se instauró, en lugar del anterior, un ejecutivo presidido por el anciano liberal Eusebio Bardají Azara que, para el Eco del Comercio, era "una mezcla de diversos colores y matices". Además, en sus cortos cuatro meses de vida tuvo una gran inestabilidad, principalmente en el Ministerio de la Gobernación, en el que sucedieron hasta cuatro titulares y otros tantos en la jefatura política de Madrid.

Esta situación no pudo por menos de afectar a dos de los cometidos políticos nucleares de este departamento: el ejercicio de la libertad de imprenta y la práctica electoral. En el primero de los ámbitos, las principales acciones para encauzar dicha libertad o, como diria el diputado Gómez Acebo, lograr una "libertad de imprenta moralizada" se llevaron a cabo en el seno de las Cortes Constituyentes en la conclusión de su mandato. Aquí, llegándose a plantear, ante las críticas circunstancias de la guerra civil, la suspensión temporal del derecho a imprimir y publicar libremente e incluso la recuperación de la censura previa, al final, como ya hemos señalado anteriormente, mediante la ley de 17 de octubre se decidió complementar restrictivamente la anterior del 22 de marzo. Por el contrario, el Ministerio de la Gobernación y sus agentes se relajaron y mucho en el control de la prensa, reduciéndose sobre manera los artículos denunciados (sólo 10; 9 de diarios conservadores). También es cierto que, con la salvedad del periódico propagandístico y testimonial de La Constitución de 1837 (Periódico de política, administración, comercio y literatura), no hubo iniciativas editoriales para reemplazar a los diarios suprimidos ${ }^{12}$.

De esta manera, el desbarajuste en ese departamento ministerial facilitó que imperara una amplia libertad de prensa y que la intervención gubernativa fuera escasa en los primeros comicios legislativos celebrados a finales de septiembre bajo las nuevas Constitución de 1837 y la ley electoral de 20 de julio. En ellos la prensa de partido jugó un papel fundamental en la difusión del programa y

11 El pulso entre el Gobierno y la prensa conservadora en: D.S.C., Cortes Constituyentes, 21 y 30.06.1837, pp. 4184-4185 y 4422-4423; Eco del Comercio, 3, 4 y 5.08 .1837 y El Español, 3.08.1837.

12 Las medidas y evolución de la prensa bajo este Gobierno: D.S.C., Cortes Constituyentes, 11.09.1837, pp. 5940-5946; Eugenio Hartzenbusch, Apuntes para un catálogo de periódicos madrileños desde el año de 1661 a 1870, op.cit., p. 56; y Javier Pérez Núñez, "Gobernar Madrid bajo el régimen constitucional de 1837. Regencia de Maria Cristina”, op. cit., pp. 458-465. 
reprobación del el del adversario, en la movilización del electorado y apoyo de las candidaturas patrocinadas, y en la propia organización y desarrollo del proceso electoral. A este respecto, por el lado de los moderados, El Español contribuyó de manera muy importante a dotar a este partido de una estructura organizativa para los comicios, al divulgar la novedosa cartilla electoral elaborada principalmente por el que fuera ya su director, Andrés Borrego, y de un ideario monárquico-constitucional más actualizado, al asumir el trono de Isabel II y la Constitución como "bandera común". Otros diarios de esta tendencia, como El Mundo, se mantuvieron impertérritos en sus posiciones reaccionarias, al proponer ya una revisión de carta magna desde la perspectiva del Estatuto. Por el lado de los progresistas, a falta de directrices gubernativas, fue El Eco del Comercio el gran referente para los ayuntamientos y diputaciones que, en la órbita de esta formación política, eran los encargados de los trámites principales de las elecciones ${ }^{13}$.

\section{LOS MODERADOS REPRUEBAN EL JUICIO POR JURADOS.}

Al triunfar en estos comicios los moderados se hicieron con el control de las Cortes y, seguidamente, del Gobierno, que hasta finales de 1838 estuvo presidido por dos ancianos realistas templados, primero, el conde de Ofalia y, después, el duque de Frias. Paulatinamente, fueron desvelando la necesidad de superar la Constitución de 1837 y, mediante otra transacción con el carlismo, retrotraerse al régimen estatutario. Esta reubicación supuso un importante cambio de perspectiva ideológica tanto de los distintos grupos politicos como de la prensa de opinión. Una visión que, además, se encontraba muy distorsionada porque la principal información recibida por las autoridades gubernativas era la proporcionada por la policía. Este cuerpo de protección y seguridad que, proveniente de la segunda etapa del absolutismo fernandino, entonces fue reactivado, mantuvo los presupuestos realistas originarios y la misión primordial: evitar la revolución. De esta manera la idea de la conspiración se convirtió en algo obsesivo y a ella adscribían a todos los que se situaran en la oposición al partido y, sobre todo, al Gobierno conservador.

Pues bien, considerando a Madrid el principal escenario de la conspiración, los agentes y delatores policiales la canalizaban alrededor de distintas sociedades más o menos clandestinas, cuyos miembros se reunían en domicilios privados y espacios públicos (principalmente cafés) y divulgaban sus idearios a través de periódicos ya existentes o creados al objeto. Así, con escasa precisión, vinculaban a las sociedades republicanas y democráticas como la Joven España o la de los Derechos del Hombre con diarios de signo progresista, la primera con el Eco del Comercio y la segunda con El Progreso, diario liberal fundado a mediados de marzo de 1838, cuyo editor propietario y director era Ignacio Boix y sus principales redactores Manuel Gutiérrez y Mariano Carnicero. Además, estos periodistas desde el mes siguiente ocuparon idéntico cometido en el Amigo del Pueblo, periódico bimensual ideológicamente afin, estrenado entonces.

13 Para la prensa durante las elecciones: Natividad Araque Hontangas, Las elecciones en el reinado de Isabel II: la Cámara baja, Madrid, Congreso de los Diputados, 2008, pp. 143-155 y Javier Pérez Núñez, "Gobernar Madrid bajo el régimen constitucional de 1837. Regencia de Maria Cristina”, op. cit., pp. 459-461. 
Obviamente, hubo otros diarios más cercanos a esas propuestas entonces radicales, como fueron los efimeros El Correo de los pobres o El Extravagante y, con una vida más dilatada y una mayor audiencia, según la policía, entre "las masas toscas e ignorantes", el Mensajero del Pueblo. Tuvieron una incidencia mayor, aunque fuera momentánea, los folletos u hojas volantes, como el Duende los Misterios o el Indicador que, calificados por las autoridades gubernativas de "altamente incendiarios", fueron difundidos en la concurrida Puerta del Sol y al parecer redactados en las reuniones de los cafés (Príncipe, Dos Amigos, Nuevo) por los principales cabecillas de las tendencias democráticas (Ángel Iznardi, Lorenzo Calvo Rozas o Luis González Bravo, entre otros).

Como, según los agentes policiales, los progresistas al igual que los anteriores no hacian otra cosa que conspirar, recurrian a los mismos canales clandestinos. Principalmente, al "club tenebroso de los antiguos templarios sublimes o conocido con la denominación de mineros" (en memoria del general Mina), del que era el gran maestre y lo financiaba, y para la policía centro de todas las conspiraciones, Juan Álvarez Mendizábal, y las altas dignidades eran destacados exministros, diputados y generales progresistas (como Agustín Argüelles, José María Calatrava, Facundo Infante, Vicente Sancho, Antonio Seoane, Evaristo San Miguel...). Mantenía relaciones con otras sociedades europeas con señas masónicas y liberales y propagaba su discurso en las páginas de los citados Eco del Comercio, El Progreso, así como el Patriota, hasta su desaparición a mediados de julio, y, específicamente en el ámbito militar, a través de la Revista militar, periódico mensual, redactado por Evaristo San Miguel. Pues bien, con esa sociedad "minera", para la policia, los progresistas, como en los veranos de 1835 y 1836, volvian a situarse en la agitación, sin más objeto que para intentar recuperar el poder recientemente perdido.

Más allá del gusto romántico por este tipo de sociedades secretas, no parece que el club clandestino progresista tuviera la importancia que le confería la policía. Una influencia bastante superior, a nuestro entender, tuvieron las reuniones de los diputados de Madrid (principales líderes del partido) celebradas en la sede del Eco del Comercio, centro político e ideológico de esta formación. También resulta excesivo el radicalismo que le hacian profesar y provenía sobre todo de la propia ubicación del cuerpo policial en los márgenes del realismo. Con todo, cierta inclinación era indudable y se encontraba implícita en el propio retorno a la oposición, así como en la necesidad de tender puentes con la tendencia más avanzada del partido, la doceañista, que se había acantonado en las corporaciones locales de las ciudades más importantes. Así, con el sesgo radical se buscaba la confluencia de las corrientes del progresismo, pero también la involucración de estas instancias, sobre todo las de Madrid, principal bastión entonces del progresismo, en la oposición al Gobierno conservador ${ }^{14}$.

Así, lo hicieron estas corporaciones, fundamentalmente el Ayuntamiento de la capital, impugnando "con patrióticas representaciones sus demasias",

14 Para identificar las distintas fuerzas de oposición y los medios de difusión hemos seguido a: Archivo General de Palacio (en adelante, A.G.P.), Reinados, Fernando VII, 28/31; Archivo de la Real Academia de la Historia (en adelante A. R. A. H.), Archivo particular de Isabel II, serie $1^{\mathrm{a}}$, leg. 7: partes de policia a la regente y al Gobierno, 1838; Eco del Comercio, 19.06 y 8.07.1838; Antonio Eiras Roel, "Sociedades secretas republicanas en el reinado de Isabel II", Hispania, 86 (1962), pp. 273-280; y Eugenio Hartzenbusch, Apuntes para un catálogo de periódicos madrileños desde el año de 1661 a 1870, op. cit., pp. 56-60. 
particularmente con ocasión de los debates de las Cortes sobre temas y acontecimientos controvertidos, como los referidos al proyecto de reforma censitaria y centralizadora de la administración local, a la trayectoria de la guerra civil, a las abusivas declaraciones de estado de sitio y a las actuaciones represivas de algunos comandantes militares de Andalucía y Cataluña. De esta manera se formaria una especie de tándem con la prensa progresista, siendo el Eco del Comercio y el Ayuntamiento de Madrid su mejor expresión. Algo que desagradó sobremanera al ejecutivo moderado. Por eso, aunque estas instancias territoriales contaran con la cobertura legal de la normativa régimen local vigente de 1823, esta agregación a la oposición le parecía una manifiesta extralimitación y para rebatir estas exposiciones recurrió a la Gaceta de Madrid. Así, como en la época del Estatuto Real, el diario oficial del Estado se volvió a convertir en un medio de propaganda y de difusión del ideario del partido gobernante. Sensu contrario, las dificultades para el control gubernativo de los Boletines Oficiales de las provincias y su conversión, según el Ministerio de la Gobernación, en "órganos de los partidos y opiniones politicas de sus redactores", le impelieron a recordar el 13 de julio de 1838 su carácter oficial y la exclusión de la publicación de noticias y discusiones políticas, entre otras razones, porque "los editores de estos periódicos no estaban sujetos al depósito y demás requisitos de la ley de imprenta" 15 .

Se recurrió otra vez a la Gaceta por la difusión que tenía, dada la suscripción obligatoria para las autoridades territoriales, y porque sus artículos aparecian conferidos de una mayor autoridad al contar con el marchamo oficial, pero también por la escasez de la prensa afín al Gobierno. Así, el apoyo militante del ejecutivo se reducía en lo fundamental a los diarios El Mundo y La España, y la reaccionaria Revista de Madrid, inaugurada a principios de año por Pedro José Pidal y Gervasio Gironella. En esta línea ideológica, pero preocupado, sobre todo, de las doctrinas, noticias y documentos religiosos católicos, estaba La Voz de la Religión, que perduró hasta 1841 y desde el siguiente año tuvo su continuación en El Reparador.

Se encontraban en el mismo espectro conservador, pero eran menos gubernamentales, El Castellano y El Correo Nacional, periódico éste que, nacido a mediados de febrero bajo la dirección de Andrés Borrego y colaboración de afamadas plumas (Antonio Alcalá Galiano, Antonio Benavides, Juan Bravo Murillo, Juan Donoso Cortés, Alejandro Oliván, Joaquín Francisco Pacheco, Antonio Ríos Rosas, etc.), recuperaba en principio la linea editorial originaria conservadora templada de El Español, desaparecido a finales de 1837. En este mismo marco y contando con la participación de dos de sus redactores, Santos López Pelegrín ("Abenámar") y Antonio María Segovia ("El Estudiante"), saldrian a la luz por las mismas fechas el periódico "satírico, político y literario" titulado

15 Para la participación de las corporaciones locales madrileñas en la oposición política: A.V.M., Secretaría 2/440/62; Eco del Comercio, 28.02 y 9.03.1838; y Javier Pérez Núñez, "Gobernar Madrid bajo el régimen constitucional de 1837. Regencia de María Cristina”, op. cit., pp. $482-485$ y 494-497 Para las publicaciones oficiales: A.H.N., Consejos, 11.324/1, 44 y 72; Gaceta de Madrid, 12.02 y 11, 12 y 13.09.1838; y Marta Lorente Sariñena, La voz del Estado, op. cit., pp. 94-95. 
Nosotros y con la conclusión del año el más personalista Abenámar y El Estudiante. Capricho periodístico ${ }^{16}$.

Estas publicaciones estaban más abiertas a los distintos planteamientos surgidos en el seno del partido moderado que, al igual que progresista, no había logrado aún ni una verdadera cohesión ideológica ni un auténtico liderazgo. Así, tanto El Castellano como El Correo Nacional dieron cobertura a la propuesta de formación de un "tercer partido", a la que se vinculaba, no siempre juntos, al grupo disidente del progresismo liderado por el exministro Pío Pita Pizarro, al general Fernando Fernández de Córdoba, enfrentado con el general en jefe del ejército del norte Baldomero Espartero, y al infante Francisco de Paula, al que se pretendía convertir en regente.

La promoción de estos objetivos era el cometido principal del periódico El Graduador. Contaba con el respaldo financiero del conde Parcent, mayordomo mayor del infante, y del banquero N. Safont, tenía a Juan Muñiz Miranda como editor responsable y seguía el modelo del diario político sarcástico El Hablador, estando encargado del apartado satírico-jocoso N. Castañeda, que había sido redactor de éste, y del político B. Fernández Pereira. Pues bien, el 2 de abril inició su andadura y lo hizo de forma bastante desvergonzada, no sólo porque con el primer ejemplar del diario se regalara un retrato del infante, sino, y sobre todo, porque sus artículos denigraban sobremanera al Gobierno, a la regente y al entorno de la Corte. De esta manera, que lo que pretendiera, según informaba la policía, fuera la promoción ministerial del citado Pío Pita Pizarro, no era lo importante, sino que se quisiera alcanzar por medio del escándalo público: del número del 3 de abril con un contenido semejante al del día anterior se vendieron 1.000 ejemplares. Por eso, ante lo que se consideraba "el abuso más escandaloso de la libertad de prensa", el ministro de la Gobernación, el marqués de Someruelos, tomó cartas sobre el asunto e impelió al jefe político de Madrid, Francisco Romo Gamboa, a que, exhortando a los promotores fiscales, presentara la correspondiente denuncia y tomara las providencias indispensables "para minorar, si no fuera posible cortar de raíz, las perniciosas consecuencias de semejantes excesos, encaminadas visiblemente a minar el trono legitimo y hacer odiosa la libertad". Así lo hizo este delegado gubernativo cuando se sucedieron artículos con mismo cariz y se conoció la absolución del jurado a los dos primeros números denunciados. Finalmente, el 8 de abril fue suspendida la publicación de El Graduador y su editor responsable fue detenido y, después de ser declarados punibles el resto de los artículos denunciados, fue condenado a cuatro años de prisión.

El propósito inmediato de los promotores de este diario era reeditarlo bajo una nueva cabecera. No se llevó a cabo cuando se evidenció que la acción contra El Graduador no había sido un hecho episódico. Así, el 12 de abril era detenido Antonio Granados, capitán retirado y editor responsable del periódico El Hablador, por la denuncia interpuesta por un artículo publicado en el número del día 6 considerado sedicioso, y se suspendía su publicación hasta tanto contara con un nuevo editor responsable autorizado. Una vez superadas las trabas y retrasos gubernativos, lo consiguió, pero, después de ser desterrado su director,

16 Para la prensa conservadora: Eugenio Hartzenbusch, Apuntes para un catálogo de periódicos madrileños desde el año de 1661 a 1870, op. cit., pp. 56-60; y María Cruz Seoane y María Dolores Saiz, Historia del periodismo en España. 2. El siglo XIX, op. cit., pp. 176-180. 
Bartolomé Prato, por las críticas al ejecutivo en torno al asunto de las llamadas viudas de Comares, acabó sucumbiendo el 16 de julio.

Ya bajo el mandato del siguiente jefe político de Madrid, el coronel retirado Diego Entrena Mosquera, el 20 de agosto llegó el turno a Rafael Santos Guzmán, editor responsable del periódico El Progreso. Aquí, al parecer, estaba colocado como redactor N. Castañeda, que lo había sido las dos anteriores publicaciones, y se estaban publicando artículos inéditos escritos para el desaparecido diario $E l$ Graduador. Después de esa detención, El Progreso tardó un tiempo en salir a la luz porque, según la policía, se quería contar con tantos editores responsables como los que se pudieran sustituir durante la campaña de seis números seguidos con artículos sediciosos y subversivos que pensaban publicar. Pues bien, si se llevó a cabo tal operación, sólo dos de ellos fueron denunciados por los promotores fiscales, además con una calificación menor, y fueron absueltos por el jurado ${ }^{17}$.

Este desajuste resulta bastante normal porque la policía tiende a cargar las tintas sobre los periódicos de la oposición liberal, viendo detrás de cada uno de ellos "un papel de la revolución". No obstante, las autoridades gubernativas a la hora de valorar esta prensa seguían la información facilitada por ese instituto. Así, en ella se encuentra la base del aumento considerable de denuncias, particularmente de los citados diarios, durante el Gobierno del conde de Ofalia en comparación con las efectuadas en el transcurso del segundo semestre de 1837, desde que se aprobó la Constitución hasta que al comienzo de 1838 se instaló el nuevo jurado censitario ajustado a la ley de 17 de octubre de 1837 . A lo largo de este tiempo, que nosotros hemos tildado de desbarajuste gubernativo, se produjeron 19 denuncias, 17 de artículos de periódicos conservadores, 1 de progresistas y 1 folleto. En el siguiente periodo, hasta finales de agosto, el del ejecutivo conservador señalado, hubo 53 denuncias, 18 de artículos de periódicos conservadores, 32 de progresistas y 3 folletos.

Si seguimos la comparación y observamos el recorrido de las denuncias se debe matizar algo el crecimiento del último año. En el segundo semestre de 1837 dominan las denuncias a los diarios conservadores, considerando, además, el jurado de la acusación que debía continuarse el proceso en 12 de ellas (de 17) y en el folleto, pero no con la única denuncia progresista. El curso que el jurado dio a las denuncias de ocho primeros meses de 1838 fue un tanto diferente: se consideró que debía formarse causa a 11 de los artículos denunciados de la prensa conservadora y a otros tantos de la progresista, pero de un total de 18 en caso de los primeros (61\%) frente al de 32 en los segundos (34\%).

Esta inclinación de los jurados en favor de la prensa progresista y en detrimento de la conservadora soliviantaba a las autoridades gubernativas. De ahí el ya observado reajuste realizado por éstas y también el intento de controlar la formación de esos tribunales ciudadanos. Así, adecuada desde principios de año la lista de los jueces de hecho de Madrid a las exigencias censitarias (el pago de 500 reales de contribución directa), Diego Entrena intentó fiscalizar los sorteos de los jurados tanto de la acusación como de la calificación de los escritos que se

17 Para las acciones contra esas publicaciones: A.H.N., Consejos, 11.318/2, 35 y 38 y 11.341/10; A.R.A.H., Archivo particular de Isabel II, serie $1^{\mathrm{a}}$, leg. 7, partes de policia a la regente y al Gobierno, 1838; y Demetrio Castro Alfin, Los males de la imprenta. Politica y libertad de prensa en una sociedad dual, op. cit., pp. 43-44. 
denunciaran, exigiendo al Ayuntamiento madrileño le informara con anterioridad de su celebración, en cuanto "autoridad encargada de proteger las garantias políticas consignadas en la Constitución”. Así se lo requirió al alcalde de la capital el 16 de julio y, ante la negativa de éste de acuerdo con el pleno de la corporación municipal por considerar que tal comunicación no estaba contemplada en la legislación de imprenta, la orden del 23 de agosto agregó a esta normativa el aviso anticipado de los sorteos a los jefes políticos, para que "pudieran velar su exacto cumplimiento".

Paradójicamente, el marqués de Vallgornera, ministro de la Gobernación del Ministerio del duque de Frias establecido en septiembre, ni ahondó en esta vía ni tampoco en la más drástica contra la prensa de la oposición. No hizo nada, y así lo demuestra el exiguo número de denuncias efectuadas, y, al tiempo que crecía la oposición fuera y dentro del partido, en las Cortes y en las tertulias, en el ámbito civil como en el militar, se acabó desatando una campaña mediática antigubernativa, a la que, salvo los conocidos periódicos adictos, se sumaron todos los rotativos de Madrid. Este escrupuloso respecto de la libertad de imprenta, producto de la debilidad gubernativa, hizo que en la camarilla de la Corte se encendieran todas las alarmas porque -como apuntaba un parte de un confidente a la regente- "el imperio que ejercía la imprenta sobre los ánimos era de tal naturaleza, que podía decirse era un poder superior a cuantos existian y servian para exaltar las pasiones" (...) y, por eso, era "el arma más eficaz que tenían los revolucionarios"18.

El nombramiento a finales de 1838 del Gobierno presidido por el anciano diplomático y político conservador Evaristo Pérez de Castro tranquilizó algo la situación, pero no la recondujo en el sentido retrógrado que hemos visto. Hubo que esperar a que, con la remodelación ministerial de mayo de 1839, dominara sesgo más conservador del moderantismo y si encargara de la cartera de la Gobernación Juan Martín Carramolino. Hasta entonces, el jefe político de Madrid, José María Puig, de ese mismo talante, hizo lo que pudo. Lo que le producía mayores desvelos era El Guirigay. Este periódico, que apareció con el comienzo del último año, tenía "por bandera la ley política de 1837 en su más ancha expresión", es decir, la democrática mediante una lectura doceañista de la misma. Pero la enarbolaba de manera muy demagógica y populista, y de forma, más que satírica, como se autodefinía, insultante y provocativa. Era su editor responsable Isidro Sánchez Caro y sus fundadores y principales redactores Manuel Antonio de las Heras, conde de Sanafé, Luis González Bravo (autor de las famosas cencerradas firmadas como "Ibrahim Clarete") y el abogado Juan Bautista Alonso, pero la policía situaba detrás a la sociedad de los Derechos del Hombre, cuya sede la ubicaba en la casa de Madrid de este último y la vinculaba la tendencia progresista radical liderada por Joaquín María López.

No fue sólo la permanente denigración sin pudor alguno de los ministros y de la reina gobernadora, sino también, y, sobre todo, la propagación de las consideradas "doctrinas anárquicas y antisociales", lo que impelió a José María Puig a tomar cartas sobre el asunto. Así, a su iniciativa se debió la orden de 6 de

18 Para resoluciones de los jurados y el control de los sorteos: A.V.M., Secretaría, 1/227/25, 3/466/11 y 4/163/6; y Eco del Comercio, 1 y 5.09.1838. Para la campaña anti-gubernativa: A.R.A.H., Archivo particular de Isabel II, serie $1^{\mathrm{a}}$, leg. 7, partes de policía a la regente, octubrediciembre, 1838 . 
febrero del titular de Gobernación a los delegados gubernativos, especialmente al de Madrid, para que excitaran el celo de los promotores fiscales para que examinaran escrupulosamente los periódicos y escritos políticos publicados y denunciaran los que encontraran insertos en la "tendencia marcada, aunque sagazmente encubierta, a propagar doctrinas subversivas y disolventes". De esta manera se daba cobertura a la reunión de los promotores fiscales de la capital suscitada previamente por el jefe político de Madrid, en la que se encargó al fiscal Joaquín San Miguel la inspección del diario El Guirigay, al que se refería principalmente la anterior resolución.

También se volvió a recurrir a la Gaceta de Madrid, pero no tanto para contraatacar a este periódico, como para buscar la complicidad de todas las personas afectas -se decía en el número de 9 de febrero- a los "partidos liberales legales" con la actuación gubernativa contra la "ignominiosa" publicación de $\mathrm{El}$ Guirigay. Esta connivencia no se consiguió de los jueces ni de los tribunales de la acusación ni los de la calificación. Así, concentradas en ese diario la mayor parte de las denuncias efectuadas hasta finales de mayo, 13 de 21 , solo en 4 casos se celebraron los juicios acusatorios, resultando, además, en todos ellos absuelto. Más aún el artículo citado de la Gaceta fue denunciado por El Guirigay; eso sí no se accedió a la formación de causa.

La clave de la situación se encontraba en el jurado. Pues bien, José María Puig con el objeto de frenar lo que a todas luces era una "general propensión a absolver toda especie de escritos, aún los más violentos y subversivos", siguiendo los pasos de su antecesor hasta octubre de 1838, Diego Entrena, decidió intentar influir en su formación en los actos de sorteo de los jueces de hecho mediante la ampliación del aviso anticipado de su celebración al jefe político a la presencia en los mismos de los promotores fiscales. Una pretensión que fue rechazada tajantemente por el Ayuntamiento por estimarla ofensiva a su integridad como administración pública y porque, pareciéndole una extralimitación legislativa, desnaturalizaba el jurado ${ }^{19}$.

Puesto al frente del Ministerio de la Gobernación, Juan Martín Carramolino, antes de la celebración de las elecciones convocadas para agosto, consideraba imprescindible eliminar los abusos y escandalosos excesos que, a su juicio, se cometían en el ejercicio de la libertad de imprenta. Con tal objeto aprobó la orden de 5 junio de 1839, cuya justificación, contenida en el preámbulo, era un alegato contra la condescendencia de sus antecesores, porque con ella -incidia- el ejercicio de ese derecho "había degenerado en un desenfreno tan funesto y lastimoso, que hería y mataba la misma libertad". Señalaba, además, el ministro, que todo valía y se podía publicar -"las doctrinas anárquicas y disolventes con el intento de descarriar la opinión, concitar las pasiones y desquiciar al Estado"- y nada ni nadie se escapaba de la "pluma emponzoñada", "ni la moral ni la religión, pero tampoco ni los altos funcionarios ni los simples hombres honrados".

19 Para la prensa y actuación del jefe político de Madrid: A.H.N., Consejos, 11315/2,18, 22, 30 y 78, y 11341/10; A.R.A.H., Archivo particular de Isabel II, serie $1^{\text {a }}$, leg. 7, partes de policía a la regente, febrero 1839; A.V.M., Secretaria, 4/163/6; Gaceta de Madrid, 9.02.1839; Pedro Gómez Aparicio, Historia del periodismo español, op.cit., vol. 1, pp. 255-258; María Cruz Seoane y María Dolores Saiz, Historia del periodismo en España. 2. El siglo XIX, op cit., pp.180-182; y Antonio Torija Carresse, El Guirigay, los ministros y Espartero, Madrid, Imprenta de D. Salvador Albert, 1839, pp. 5-20. 
Como esta situación, para el responsable de la Gobernación, era inaceptable y no se podia esperar a que las nuevas Cortes aprobaran la necesaria legislación correctora que pensaba proponer, con esa disposición dando un nuevo paso retrógrado a ley de 17 de octubre de 1837, se procedía a recuperar sin ambages la censura previa. De otra manera no se puede entender la obligación de presentar al jefe político los ejemplares de los periódicos dos horas antes de su distribución para que los pudiera examinar por sí o por personas de su confianza y, en el caso de que hubiera "artículos capaces de comprometer, que atacaran la religión u ofendieran la moral, las costumbres o el pudor", impedir su circulación y presentarlos a la calificación del jurado, También se prohibía pregonar por las calles la venta de hojas sueltas o periódicos, y se controlaba la composición y actuación del jurado ordenando la rectificación de las listas de los jueces de hecho, la asistencia de los promotores fiscales a los sorteos y establecimiento de las necesarias precauciones para evitar las coacciones en los juicios públicos.

Inmediatamente en Madrid, al tiempo que el jefe politico circulaba la nueva reglamentación, periódicos de distinto signo (Eco del Comercio, El Correo Nacional, El Castellano, El Guirigay, El Constitucional y Fray Gerundio; estos dos últimos eran diarios progresistas, el primero una reedición del de 1837 con una vida tan como la anterior, solo de abril a agosto, y el segundo el periódico satírico-político redactado por el historiador Modesto Lafuente y publicado en la capital desde julio de 1838) formaron un frente común contra los que consideraban una arbitrariedad y atropello a un derecho constitucional. Al final esta oposición parece que dio sus frutos porque la nueva exigencia gubernativa en la capital no se llevó a cabo, por lo menos de manera habitual. Obviamente, para otras publicaciones, como la reaccionaria Revista de Madrid, la nueva orden le parecía insuficiente e ineficaz para contener unas demasias periodisticas, que pintaba con tono aún más exagerados que el ministro.

Como ya hemos señalado, las extralimitaciones para las autoridades gubernativas provenían ante todo del periódico El Guirigay y para frenarlas estaba precisamente indicada la disposición aprobada. Por encontrarse en la misma línea periodística y política, también lo estaba para El Diablo suelto, periódico popular de la mañana que salió a la luz el 1 de junio. Así, fueron distintos números de estos diarios los que vieron suspendida la circulación por contener, a juicio de José María Puig, artículos inadmisibles.

La opinión de los jurados fue bastante diferente a la del jefe político. En el caso del último periódico, en ninguno de los artículos denunciados por el promotor fiscal el tribunal ciudadano estimó debía procederse a la formación de causa. Con todo, la parálisis diaria a la que vio sometido, acabó por hacerle sucumbir al terminar junio. Por el contrario, sí lo consideró para dos artículos denunciados de El Guirigay, reuniéndose los días 16 y 20 de junio en la capilla de San Isidro los correspondientes tribunales de la calificación. En ambos, ante una importante concurrencia y una defensa aprovechada por sus redactores, Juan Bautista Alonso y Luis González Bravo, para difundir las ideas democráticas profesadas por el diario y verter acusaciones de absolutistas al Gobierno y sus delegados, los jurados fallaron por la inocencia. Concluyeron los actos con "vivas a la libertad y mueras a los tiranos", proferidos por el público asistente.

Para el ejecutivo, y principalmente para el ministro de la Gobernación, la situación había llegado ya a un límite infranqueable y decidió poner fin al círculo vicioso al que se referia la muy conservadora Revista de Madrid: “(...) el escándalo 
de la prensa crecía y se aumentaba en los debates judiciales, en que (...) después de verse la autoridad judicial reprimida entre vociferaciones y aplausos partidarios del acusado, de verse convertido el foro en una cátedra del escándalo, de la difamación y la anarquía, venía por lo común un fallo de un jurado mal ideado, peor elegido y en muchas ocasiones poco libre en sus votos a sancionar un escándalo, y dar nuevas esperanzas a liberalistas y folicularios". Para intentar terminar con esta encrucijada se dieron tres pasos: la suspensión ejemplarizante de El Guirigay, el control de la edición de nuevos periódicos y la vigilancia en la formación de los jurados.

Lo primero se llevó a cabo de una forma bastante drástica. En la mañana del 6 de julio un destacamento de la policía al mando del jefe político irrumpió en el domicilio de Luis González Bravo con la intención de detenerle por un artículo publicado en el citado diario, que, al parecer, era ofensivo contra la regente y el titular de la Gobernación. Consiguió huir y publicó una hoja volante, en la que manifestaba que, frente al despotismo, El Guirigay se "levantaba más fuerte que nunca". No fue así. Al día siguiente, el Gobierno, contando con el parecer unánime de los ministros, porque "la salud del Estado lo reclamaba imperiosamente", resolvió su suspensión. Hubo algunos alborotos en la Puerta del Sol contra esta decisión protagonizados por los vendedores del diario y por "partidarios de sus doctrinas e identificados con ellas", pero no fueron a mayores. Además, a principios de agosto José María Puig impidió la publicación y circulación del folleto de Antonio Torija Carrresse, El Guirigay, Los Ministros y Espartero, un evidente apéndice del diario.

Aunque el ejecutivo acordara dar cuenta a las Cortes de los graves motivos que le habian obligado a la suspensión, para parte importante de la prensa, no sólo progresista, dicha actuación, calificada de arbitraria, significaba la suspensión de la libertad de imprenta, pendiendo la existencia de los periódicos diría el Eco del Comercio- de la suprema voluntad gubernativa. Pero no todo fueron recriminaciones. Para la prensa moderada más militante, como El Piloto periódico que, teniendo a Antonio Alcalá Galiano y a Juan Donoso Cortés como principales redactores, reemplazó a La España en marzo de 1839-, el Gobierno "había tenido el arrojo de sacrificar la letra de la ley para salvar su espíritu". En esta misma onda se encontraba el general jefe de ejército, Baldomero Espartero, ya que, en la felicitación que a través del ministro de la guerra remitió el 18 de julio al ejecutivo, manifestaba una opinión que, extralimitándose al hacerlo en nombre del ejército, en nada desmerecía a los artículos conservadores más furibundos que avalaban la censura previa.

A esta figura recuperada en parte el 5 de junio, como ya hemos significado, el Gobierno agregó el 12 otra orden que, en línea con lo denunciado por Eco de Comercio, exigía que cualquier nuevo periódico debía contar con su parecer para su publicación. Diez dias después, además, se advirtió a los jefes políticos, por lo menos al de Madrid, que debian asegurarse que los editores responsables tuvieran la calidad de contribuyentes, que los diarios se sujetaran a aquella primera norma e informar inmediatamente sobre las extralimitaciones de los artículos. Fundamentalmente lo que se perseguia con estas precauciones era evitar la reproducción de El Diablo suelto o El Guirigay bajo nuevas cabeceras. Así, se examinaron con lupa las solicitudes de los periódicos El Agente Nacional (Periódico popular de la mañana) y La Legalidad (Periódico político, científico, literario y comercial) porque, teniendo como redactores a Andrés Antonio Seijas y 
Luis González Bravo, que lo habian sido respectivamente de los anteriores, querian continuarlos. A pesar de las trabas, a primeros de agosto salieron a luz, pero, durante el tiempo en que se publicaron, su trayectoria fue mucho más apaciguada que la de sus antecesores. Con todo, se seguiría recordando a los jefes políticos que, a través de los promotores fiscales, fueran custodios del respeto, veneración y decoro que merecian en los textos impresos la familia real y los cuerpos colegisladores.

La tercera de las actuaciones indicadas a los delegados gubernativos para evitar los excesos de la prensa, era la del control de la formación de los jurados. Dada impecabilidad de sus sorteos en Madrid bajo la autoridad del alcalde constitucional, la presencia de los promotores fiscales, exigida por el ejecutivo y recurrida por el Ayuntamiento al considerarla manifiestamente ofensiva, no tuvo valor alguno. Tampoco lo tuvo contar con la nómina de los 4.319 jueces de hecho (los que pagaban más de 500 reales de contribución), requerida por José María Puig al intendente, a no ser que se buscara su adoctrinamiento conservador. Si no este planteamiento, algo parecido pretendía un sector de la opinión conservadora, ya que, a pesar de que desde la suspensión de El Guirigay y hasta el final del año hubieran caído en picado las denuncias, no solo disentía con el sistema del jurado, sino que le seguía pareciendo escandaloso la difusión determinadas ideas.

Pues bien, impedirlas era lo que pretendia Juan Martín Carramolino, a tenor del proyecto de ley sobre la libertad de imprenta presentado a las Cortes el 14 de septiembre, orientado ante todo a introducir el orden conservador en su ejercicio. Así, para ello, entre otros pormenores, se incrementaba hasta 1.000 reales la cuota contributiva exigida a los editores responsables, se sumaban penas pecuniarias a las carcelarias por los abusos infringidos, se podia suprimir un periódico que hubiera incurrido en un año en tres sentencias condenatorias, los jueces de primera instancia harian las veces de los jurados de la acusación, que eran suprimidos, y se duplicaban las cuotas contributivas y las capacidades exigidas a los jueces de hecho, pasando la formación de las listas para los jurados de calificación al control fundamentalmente del jefe político ${ }^{20}$.

Esta propuesta no pudo prosperar porque los moderados tras las elecciones de agosto se encontraron en minoria en las Cortes. Al éxito de los progresistas contribuyeron, además de las diputaciones y ayuntamientos de las mayores ciudades, los periódicos de esta tendencia, especialmente el Eco del Comercio, que difundió la unidad alcanzada por el partido en torno a las candidaturas y programa del progreso. De la misma forma, ambas instancias -corporaciones locales y prensa progresista- se sumaron a este partido en el rechazo a la decisión de la regente, primero, de mantener el Gobierno conservador de Evaristo Pérez Castro en detrimento de veredicto de las urnas y, después, de concederle el

20 Para el control de la prensa bajo el mandato de Juan Martín Carramolino: A.H.N., Consejos, $11315 / 2,30,78,79$ у 87 у 11341(I)/7, 10 у 17, 11341 (II)/ 25 у 26; A.V.M., Secretaría, 1/227/25, 26, 29 у 31, 3/466/1, 4 у 6 у 4/163/4 у 6; D.S C., 13.09.1839, p.139; D.S.C. (Congreso), 14.09.1839, apéndice cuarto al núm. 14, pp. 199-212; El Correo Nacional, 7.06. y 79.07.1839; Eco de Comercio, 7, 8, 10, 11 y 24.06. y 7-9.07 y 1.08.1839; El Piloto, 7-9.07.1839; Revista de Madrid, I (1839). Crónicas de los meses de junio y julio (Política Interior), pp. $183-185$ y 272-273. Demetrio Castro Alfin, Los males de la imprenta. Politica y libertad de prensa en una sociedad dual, op. cit., pp. 41-42; Pedro Gómez Aparicio, Historia del periodismo español...Vol. 1, pp. 258-259; y Antonio Torija Carresse, El Guirigay, los ministros y Espartero, op. cit., pp. 38-53. 
decreto de disolución, argumentando que las circunstancias habían cambiado con la terminación de la guerra civil. Así, en Madrid en apoyo de los diputados de mayoria progresista actuaron la Diputación y el Ayuntamiento de Madrid elevando una exposición a la reina gobernadora y los periódicos de esta opinión liberal como $\mathrm{El}$ Independiente (que, editado entonces, fue tan efimero como $\mathrm{El}$ Agente Nacional al que venía a sustituir) La Legalidad o El Eco de Comercio, realizando una campaña en contra del pago de las contribuciones por haberse cerrado las Cortes sin haberse aprobado los presupuestos.

Durante la campaña abierta entonces para los nuevos comicios legislativos convocados para enero de 1840, estos diarios cerraron filas en torno a la formación progresista y protestaron contra la descarada intervención gubernativa que, vulnerando la legislación, afirmaba a los jefes políticos en el proceso electoral en detrimento de las corporaciones locales. Además de difundir de nuevo el "programa del progreso", particularmente los últimos rotativos, se encargaron de que el acercamiento del influyente general Espartero a la opción del liberalismo avanzado tuviera la mayor resonancia posible.

Si la prensa conservadora censuró esta basculación del duque de la Victoria por considerarla una intromisión inadmisible de un militar en los asuntos políticos, la otra, la total involucración gubernativa en el ámbito electoral, la contempló como un simple reequilibrio de influencias y, por lo tanto, le pareció acertada la mutación de los delegados gubernativos en agentes electorales del partido moderado. A este respecto, debe significarse que, además de El Piloto y la Revista de Madrid, El Correo Nacional ocupó ya en esta formación el lugar que el Eco del Comercio tenía en la opción progresista, siendo el principal medio para movilizar al partido y a la opinión conservadora (en torno al famoso Manual de Andrés Borrego), y para difundir el programa de reorientación de la Monarquía constitucional a las lindes del Estatuto Real mediante de las reformas centralizadora de la administración local, censitaria de la normativa electoral, censoria de la libertad de imprenta (en el sentido ya señalado) y restrictiva de la formación de la milicia nacional.

Los moderados, con la excepción casi solo de Madrid, triunfaron en los comicios de forma abrumadora, al igual que lo habian hecho los progresistas seis meses antes. Este cambio tan drástico de la opinión en tan corto tiempo hizo que inmediatamente planeara sobre esta consulta la sombra de la corrupción y el fraude electoral. Así parece que fue y, por eso, se consideran las elecciones más fraudulentas de las celebradas hasta el momento, aunque la prensa conservadora las presentara como la expresión de todo lo contrario. Fueron periódicos de signo progresista, fundamentalmente el Eco del Comercio y La Legalidad, los encargados de denunciar las arbitrariedades e ilegalidades para concluir calificando a las Cortes de ilegitimas.

De esta manera estos diarios, junto a las corporaciones locales afines, se sumaron a la estrategia progresista de apoyar las denuncias de los diputados de la minoría en el Congreso, manteniendo así la movilización de la opinión y promocionando manifestaciones y algaradas de descontento. Como las que ocurrieron a la apertura de las sesiones de las Cortes, que acabaron provocando que el 24 de febrero de 1840 se declarara en Madrid el estado de sitio. Pues bien, bajo esta situación excepcional se persiguió a las personas, pero también a las ideas y otras formas de expresión. Así se contenía en el oficio que el 28 de febrero el capitán general de Madrid remitió al nuevo jefe político, Diego Entrena, en el 
que al recordarle la vigencia de la orden de 5 de junio de 1839 -la presentación previa de los ejemplares de los periódicos al Gobierno político para evitar la difusión de textos alarmantes, subversivos o injuriosos- le requería que, mientras rigiera el estado de sitio, también se enviaran antes a la Capitanía general. De nuevo el Eco del Comercio intentó formar un frente de oposición, pero esta vez no lo logró.

Durante el tiempo en que duró el estado excepcional este rotativo, La Legalidad y Fray Gerundio fueron los que más sufrieron el control gubernativomilitar con distintos artículos denunciados. Además, este último periódico el 13 de marzo -el mismo día que fallecía de muerte natural el diario reaccionario $E l$ Piloto, subrayaba el Eco de Comercio, observando en ello una suerte de represaliavio suspendida su publicación y su redactor Modesto Lafuente desterrado de Madrid por publicar una caricatura en la que los diputados de la mayoría se tragaban las actas como ruedas de molino. Para ello el nuevo ministro de la Gobernación, Saturnino Calderón Collantes, aprobó una orden ad hoc que, con fecha del día anterior, daba cabida a lo que se consideraba una nueva forma de atropello, las caricaturas, que se sumaban a los artículos e impresos que, por atentar "punible y criminalmente" contra los "objetos de veneración ya política ya religiosa", debían ser denunciados por los promotores fiscales. Esto sí que era un auténtico atropello, mayor aún si se tiene en cuenta que, ofensas parecidas publicadas en la prensa conservadora contra la minoría progresista (véase la Revista de Madrid), no recibian el mismo tratamiento ${ }^{21}$.

Con el levantamiento del estado de sitio el 18 de marzo se permitió a Fray Gerundio que reanudara su publicación, sin embargo, se mantuvo una estrecha vigilancia a la citada prensa liberal, sobre todo, porque se convirtió entonces en el principal altavoz de la oposición de la minoría progresista a la reforma centralizadora y censitaria de la administración local. Pero no por eso estos medios se contendrían un tanto, sino también porque el sector templado de este grupo liberal compartía el rechazo de la propuesta conservadora, pero no la alternativa de la vigente normativa de 1823, y buscaba el liderazgo del general Baldomero Espartero que, ideológicamente afín, tenía una particular aversión a los excesos radicales de la prensa. De ahí que La Legalidad, que tenía como aspiración -según el promotor fiscal- "fundar una nueva escuela que no merecía otro nombre que el de la perpetua anarquía", por presiones de este militar acabaría interrumpiendo su publicación el 22 de marzo.

Pero si se quería sumar fuerzas para hacer frente al partido moderado y a la regente, que inequivocamente le apoyaba en su proyecto de reconducción doctrinaria de la Monarquía constitucional, no se debía desdeñar ni el discurso ni la acción del sector radical del partido. Menos aun cuando el ideario conservador

21 Para la prensa durante las elecciones: A.H.N., Consejos, 11.318/64, 71 y $112,11.341$ (II)/25; A.R.A.H., Archivo particular de Isabel II, serie $1^{\text {a }}$, leg. 6, observaciones imparciales sobre la presente crisis y acerca de la formación del Ministerio, 6.10.1839, leg. 7, partes de policía a la regente, septiembre-octubre 1839 y leg. 8 partes de policía a la regente, enero1840; A.V.M, Secretaría, 1/227/36 y 4/163/6; El Correo Nacional y el Eco del Comercio, noviembre-diciembre 1839 y enero-febrero 1840; Concepción de Castro, Romanticismo, periodismo y politica. Andrés Borrego, Madrid, Tecnos, 1975, pp. 188-200; Natividad Araque Hontangas, Las elecciones en el reinado de Isabel II: la Cámara baja, op. cit., pp. 192-214, 236-240 y 244-248; y Javier Pérez Núñez, "Gobernar Madrid bajo el régimen constitucional de 1837. Regencia de María Cristina”, op. cit., pp. 518-522 y 535-545. 
ampliaba su difusión, aunque solo fuera hasta el verano, con nuevos diarios como La Prensa o El Publicista. Además, sin traba alguna y cuestionando abiertamente el régimen constitucional, circularon periódicos de filiación carlista como El Católico o El Restaurador.

Por todo ello, el hueco dejado por el rotativo progresista suprimido, fue cubierto con una relativa inmediatez por otro del mismo talante, pero menos radical, El Labriego. Con tal objeto, este periódico político, nacido a finales de febrero bajo la dirección de José García Villalta, incrementó la frecuencia de su tirada. De esta manera pudo difundir más ampliamente la interpretación liberal y parlamentaria de la Constitución, que abanderaba la "tertulia de 18 de junio", a la que estaba estrechamente vinculada esta publicación.

Pero, superándole con creces por la izquierda, desde el 1 de mayo comenzó a circular La Revolución. Este diario tenía como editor a Isidro Sánchez Caro, que en su momento lo había sido de El Guirigay, y como principal redactor a Patricio Olavarría, al que se calificará como "patriarca y apóstol del republicanismo" y "decano de la democracia española". Era fiel a su título y consideraba a la revolución "un acto supremo de justicia y soberanía" a fin de instaurar un régimen republicano y democrático fundado en el sufragio universal ("voto universal") y en el igualitarismo social ("repartimiento al pueblo de los bienes nacionales"). Además, para llevar a la práctica estas ideas, enlazada con la publicación, se estableció una junta revolucionaria que, según la policía, se reunía en el café llamado Venecia y estaba formada por parte "varios hombres de alguna influencia politica", como el conde de las Navas.

Como no podía ser de otra manera, con La Revolución llegó el escándalo. Así, para hacer frente a "los principios trastornadores y altamente subversivos de todo orden social", que aquí se proclamaban según el Ministerio de la Gobernación, se activaron todas las alarmas, y el jefe politico, Diego Entrena, procedió a denunciar diariamente por medio del promotor fiscal cada número publicado. Sin embargo, considerando el Gobierno que la situación había llegado a un punto que "no bastaba para la debida reparación la legislación existente de imprenta", el 6 de mayo decretó su supresión, pero con la obligación de dar cuenta a las Cortes para su conocimiento y determinación. Se justificaba esta decisión porque lo aquí publicado era visto como un "monstruoso extravío de la razón", que tenía el "pérfido designio" de destruir la Monarquía y el orden constitucional.

El general Baldomero Espartero, como era habitual en él, respaldó la resolución gubernativa. También lo hizo parte de la prensa conservadora, sumándose al apoyo consabido de la Revista de Madrid el de El Correo Nacional. Y la mayoría moderada del Congreso sin fisura alguna el 2 de junio otorgó el bill de indemnidad solicitado. Por el contrario, los escasos diputados de la minoría presentes en la cámara disintieron porque, siguiendo los argumentos utilizados por los periódicos liberales, particularmente el Eco del Comercio, suponía la derogación del artículo constitucional que reconocía la libertad de imprenta. Una vulneración que, siguiendo la estela de El Guirigay y Fray Gerundio, parecía señalaba Manuel Cortina- se había convertido en norma de los Gobiernos conservadores $y$, en este caso, se alcanzaba una cota superior, al haberse procedido al margen de las Cortes y del jurado de la acusación que, aunque hubiera sido un claro gesto de oposición al ejecutivo, había denegado la formación de causa a todas las denuncias efectuadas. 
De esta manera, considerada invalidada la acción drástica del Gobierno, Isidro Sánchez, editor de La Revolución, solicitó al jefe político la habilitación para publicar de nuevo el rotativo. Éste intentó dar largas todo el tiempo que pudo y aquél, sin autorización alguna, el 30 de mayo volvió a imprimirlo. Fue la retirada del Banco de San Fernando del depósito necesario para la edición, la que dio cobertura a la ocupación de la imprenta por un destacamento de la policía y a la requisa de los ejemplares preparados para la distribución.

Aunque la orden de 9 de junio, para evitar argucias, estableciera como nuevo requisito a los editores la presentación de las certificaciones de contribuyentes, bien de estar inscritos en las matrículas de subsidio bien en las relaciones de propietarios por frutos civiles, no pudo impedir la reaparición al siguiente dia del anterior periódico democrático y republicano, bajo la cabecera de El Huracán. Este diario, que contó como editor, primero, con Isidro Sánchez y, después, con Patricio Olabarría, tuvo una vida más larga y una nómina mayor de redactores que La Revolución. Mantenía el mismo ideario y lenguaje radical, y por eso el control que le impuso Diego Entrena fue estricto, procediendo a denunciar sus artículos desde el primero de los números. Sin embargo, todas las denuncias, y asi fue hasta septiembre, toparon con el jurado, que en todos y cada uno de los casos falló desestimando la formación de causa. Y otro tanto ocurrió con las puestas contra los periódicos progresistas, como el Eco del Comercio.

En definitiva, indicaba un informe del Ministerio de la Gobernación, se había llegado a una situación límite porque "la prensa periódica había roto todos los diques" y "todos los diarios "habian ya arrojado la máscara y, excitando abiertamente a la sedición, al trastorno, no omitian medios de cuantos creían capaces de sublevar a las masas, irritar a la milicia y pervertir la fidelidad del ejército a fin de derrocar todos los poderes constitucionales". De esta manera, embarcados los periódicos de la oposición en un enfrentamiento general con el Gobierno, el margen de actuación de las autoridades gubernativas -señalaba el mismo dossier- era francamente limitado porque "las denuncias no producian más efecto que el escándalo de una absolución, que con la impunidad aumentaba la audacia de los escritores". La clave de esta perturbación, para el autor del informe, se encontraba, obviamente, en el jurado "falto de ilustración, sin las necesarias garantias" y "sorteado acaso de un modo que no inspira la suficiente confianza (...) por hallarse esta operación encargada exclusivamente al ayuntamiento, cuyas ideas son harto conocidas". Y, por lo tanto, en una suerte de repetición, la solución -se concluía- solo la podía aportar una nueva ley de imprenta, como la propuesta del ministro de la Gobernación, Saturnino Calderón Collantes, al Senado el 23 de marzo y trasladada el 27 de mayo al Congreso. Por supuesto, era más restrictiva que la imperante, pero menos que la proyectada por Juan Martín Carramolino, manteniéndose, eso sí, la supresión del jurado de la acusación y las alteraciones introducidas en la formación de los jurados de la calificación e introduciendo, y esto era lo más novedoso, una doble vía para el control de la prensa, la judicial u ordinaria, a cargo de los promotores fiscales, $\mathrm{y}$ la gubernativa o de urgencia, que facultaba a los jefes politicos a suspender la distribución de aquellos impresos que a su juicio pudieran alterar el orden u ofender la moral, presentando denuncia en las veinticuatro horas siguientes ${ }^{22}$.

22 Hemos resuelto el desarrollo de la prensa en Madrid bajo el Gobierno conservador con la información recogida de: Archivo General Palacio (en adelante, A. G. P.), Reinados, Fernando VII, 
De la misma manera que la propuesta de éste, la de Saturnino Calderón Collantes tampoco pudo prosperar porque la revolución de septiembre de 1840 lo impidió. La reforma municipal conservadora sancionada el 14 de julio se acabó convirtiendo en el elemento desencadenante ante el rechazo generalizado que produjo en la opinión pública. En la formación de ésta tuvieron un papel destacado los periódicos antigubernamentales: “(...) nuestra insurrección contra la tiranía -subrayaria el Eco del Comercio del 18 de octubre- (...) ha tenido lugar gracias a la imponente fuerza de opinión, auxiliada con la palanca irresistible de la imprenta libre. (...) con razón es considerada como el centinela avanzado de la soberanía del pueblo". Pero en Madrid la actuación de su Ayuntamiento fue determinante, ya que con su intervención en la formación de los jurados facilitó la difusión de esa prensa y, además, se sumó a la extensión de la oposición a la normativa municipal no sólo a través de las consabidas exposiciones, sino también mediante reuniones con el vecindario y la milicia nacional (plenos públicos de la corporación, celebraciones patrióticas...). Pues bien, por estas vías paulatinamente se fue afirmando hasta constituirse en la institución clave para dar el salto a la insurrección cuando durante el verano se produjo en la capital un vacío de poder por la ausencia de la familia real, el pulso que mantuvieron la regente $y$ el general Baldomero Espartero defendiendo las propuestas, respectivamente, moderada y progresista, la suspensión de las Cortes y la sucesión ininterrumpida de Gobiernos. Así, el 1 de septiembre el Ayuntamiento de Madrid y la Diputación de la provincia conformaron una junta provisional de gobierno y, extendiéndose el ejemplo en las principales capitales, el pronunciamiento en defensa de la Constitución y de las libertades acabó triunfando cuando el 16 se confirió el Gobierno al duque de la Victoria.

Durante el proceso revolucionario se trastocó el régimen de libertad de prensa imperante con los moderados. Algunas cosas continuaron, como la utilización politica de la Gaceta de Madrid. Otras no tanto. Así la mayores fiscalizaciones y coacciones se concentraron en la prensa conservadora, especialmente en su órgano principal, El Correo Nacional. Así, siguiendo el ejemplo de lo ocurrido en Barcelona con El Guardia Nacional, la redacción de este rotativo, por apoyar la legislación municipal moderada, fue asaltada el 27 de julio por grupo de vecinos, que se llevaron algunos ejemplares del periódico, para después quemarlos en la Puerta del Sol, al tiempo que daban gritos en favor de la Constitución y de Baldomero Espartero y en contra de Andrés Borrego (el director del diario). De nuevo el 2 de septiembre se repitió la acción, pero con un carácter más intimidatorio porque fueron hombres armados los que la invadieron y se

\footnotetext{
14/19, carta de Baldomero Espartero a la regente (12.05.1840) y 15/15 Comunicación de Ministerio de la Gobernación al Presidente del Consejo de Ministros (21.08.1840); A.H.N., Consejos, 11.318/64, 73 y 118; A.R.A.H., Archivo particular de Isabel II, serie $1^{\mathrm{a}}, \mathrm{leg} .8\left(2^{\mathrm{a}}\right.$ parte) partes de policía a la regente firmados por C. F. (1840); A.V.M., Secretaría, 1/227/36 y 4/163/6; D. S. C. (Congreso), 12.05 y 1 y 2.06.1840, pp. 1.651, 2133-2139 y 2.161- 2178; D.S.C. (Senado), 23.03 у 4, 18, 20 у 27.05.1840, pp. 109-118, 475-482, 649-650, 685-686 y 770-777; Gaceta de Madrid, 8.05.1840; El Correo Nacional, 20.4 y 12 y 16.05.1840; Eco de Comercio, 9.05 y 6.06.1840; Revista de Madrid, I (1840), crónica del mes de mayo, pp. 91-92; Demetrio Castro Alfin, Los males de la imprenta. Politica y libertad de prensa en una sociedad dual, op. cit., pp. 4445 y 55-56; Pedro Gómez Aparicio, Historia del periodismo español, op. cit., vol.1, pp. 261-264; Eugenio Hartzenbusch, Apuntes para un catálogo de periódicos madrileños desde el año de 1661 a 1870, op. cit., pp. 58-59; y María Cruz Seoane y María Dolores Saiz, Historia del periodismo en España. 2. El siglo XIX, op. cit., pp. 176-177.
} 
llevaron la mitad del molde, amenazando con su destrucción si se volvía a editar El Correo Nacional. El 7 de septiembre reapareció, pero no pudo contar con algunos de sus principales columnistas, como Juan Bravo Murillo, Manuel Pérez Hernández y Joaquín Francisco Pacheco, que acabaron siendo desterrados y confinados fuera de Madrid.

No sólo a los periódicos conservadores se estrechó la vigilancia, también a los más avanzados y radicales. Este control, además, se intensificó cuando se hizo con las riendas de la situación el liberalismo progresista más contenido, el mismo que había asumido la dirección tras la movilización de 1836 y dominado las Cortes Constituyentes, y con el que era coincidente Baldomero Espartero. Los planteamientos republicanos y democráticos, presentes en un sector de la insurrección y que tenian en Madrid en El Huracán su principal órgano de opinión, no tenían cabida y, por eso, debían ser neutralizados. Así, sus números 71 y 72 de los dias 2 y 3 de septiembre fueron denunciados por publicar sendos artículos en los que, entre otras cosas, se ponian en entredicho a la regente y a la forma de gobierno monárquica. El segundo de los ejemplares, en una suerte de aplicación de la norma moderada de 5 junio de 1839, vio suspendida circulación por orden del jefe politico Juan Lasaña Mathe. No se conoce que fuerza armada ejecutó este mandato, lo que sí está claro es que los jefes y oficiales de la milicia nacional madrileña, que habian manifestado a la junta su aversión a los principios de ese diario, recibieron con alborozo su suspensión. Tampoco sabemos si reinó este mismo entusiasmo cuando se conocieron los fallos de los jurados de la acusación, resolviendo en ambos casos que había lugar la formación de causa, y de la calificación, declarándolos subversivos y condenando a su editor, Diego José del Mazo, a 6 y 4 años de prisión, respectivamente.

Pero no sólo la abolición de la Monarquía y la afirmación del principio de la soberanía popular pretendidas por ese diario superaban con creces al ideario del progresismo que iba dominando, sino las propuestas de organización federal del Estado también contempladas. Tanto más cuanto bajo su paraguas se cobijaba la demanda de formación de una junta central, apadrinada por el sector radical de los sublevados. Pues bien, como en las páginas de El Huracán se publicaban los distintos planteamientos, acciones y convocatorias para la constitución de esta junta, se dieron instrucciones precisas al jefe politico para que impidiera en la medida de lo posible la difusión del diario. La constitución definitiva de Gobierno de Baldomero Espartero a principios de octubre y la supeditación al mismo de las juntas provinciales pondría fin al proyecto de creación de una instancia insurreccional superior ${ }^{23}$.

23 Para la revolución de 1840 en Madrid hemos seguido nuestro artículo "La revolución de 1840: la culminación del Madrid progresista", Cuadernos de Historia Contemporánea, $\mathrm{n}^{\circ} 36,2014$, pp. 151-164. Y para las cuestiones relacionadas con la prensa: A.G. P., Reinados, Fernando VII, 15/7; Boletín Oficial de Madrid, 5.09.1840; El Correo Nacional, 7.09.1840; Eco del Comercio, 6.09.1840; El Huracán, 3 y 4.09 y 10 y 13.10.1840; Concepción de Castro, Romanticismo, periodismo y política. Andrés Borrego, op. cit., pp. 206-212; y Detalles históricos del célebre pronunciamiento de Madrid, el $1^{\circ}$ de septiembre de 1840, Madrid, Boix, 1840, pp. 41-42, 58-60, $79-82$ y $123-127$. 


\section{CASI TODOS CONTRA BALDOMERO ESPARTERO: LA FORMACIÓN DE LA COALICIÓN DE LA PRENSA.}

Durante el tiempo que, después de la renuncia de María Cristina, el ejecutivo del duque de la Victoria actuó como Ministerio-regencia, se mantuvo con la prensa una actitud bastante liberal. Esto en modo alguno contradecia ni la oposición, de una parte, a la deriva democrática y federal del republicanismo y, de otra parte, a la basculación reaccionaria del moderantismo hacia el régimen del Estatuto, ni la ubicación del Gobierno en el progresismo contenido, respetable y de orden. Y era así, porque para atraer a la población a este liberalismo, se partía con la ventaja de contar con la gran popularidad que disfrutaba Baldomero Espartero, derivada de su papel nuclear en la conclusión de la guerra civil y afirmación irreversible del régimen constitucional, pero también de su ascendencia social y origen de su poder. Esta adhesión popular se quería afianzar mediante la militarización nacional, que no suponía sólo que los colegas militares del duque de la Victoria, los ayacuchos, ocuparan los puestos claves en la gobernación del Estado, sino también mediante la mayor involucración de la población a través de su ampliación en la milicia nacional y su conversión en la fuerza ciudadana de régimen, así como el adoctrinamiento mediante un discurso nacional (castrense y populista) ${ }^{24}$.

Más o menos por estas vías se pensaba que, recordaba Antonio Pirala, la prensa de oposición paulatinamente no sólo reduciría el número de cabeceras, sino también los artículos más radicales y provocativos. Pues bien, en Madrid no se produjo ni lo uno ni lo otro. Así, la opinión conservadora, que con sus principales representantes había sido excluida de las instituciones, no sólo mantuvo sus principales rotativos -El Correo Nacional, El Castellano y El Corresponsal, a las que se sumaban las reaccionarias Revista de Madrid y El Católico-, sino que contaría entre diciembre de 1840 y marzo de 1841 con El Trueno, periódico satírico, antiesparterista y al servicio de María Cristina. También la opinión más avanzada agregaría a El Huracán durante un tiempo parecido al anterior a El Pueblo Soberano y algún que otro folleto publicado esporádicamente. Por su parte, la prensa progresista se encontraba en sus horas más bajas, ya que después de cesar El Labriego, sólo estaba representada por Fray Gerundio y, sobre todo, el Eco del Comercio. Además, situados éstos, y principalmente el último, en el progresismo radical, que abogaba por la regencia trina, para contrarrestarle el ejecutivo a comienzos de 1841 promovió la publicación de La Constitución, periódico dirigido por Jacinto Salas Quiroga al servicio de la persona y el ideario de Baldomero Espartero.

Pero que la prensa disfrutara en la capital de una amplia libertad, no suponía que no se produjeran excesos, por lo menos en el sentir de las autoridades gubernativas. Así, el jefe político, Juan Lasaña, ante la impunidad en la que se quedaban los artículos que, publicados, sobre todo, en El Trueno, El Huracán y El Pueblo Soberano, realizaban una oposición sistemática y despiadada al Ministerio-regencia, denigrando y ofendiendo a sus miembros, decidió reunir a los promotores fiscales para excitar su celo. También parece que detrás de la

24 Seguimos las reflexiones realizadas en nuestro trabajo "El populismo esparterista. Discurso, milicia y celebraciones nacionales" en F. Luengo Teixidor y F. Molina Aparicio, eds, Los caminos de la nación. Factores de nacionalización en la España contemporánea, Granada, Comares, 2016, pp. 221-225. 
relajación de estos magistrados, se encontraron los atropellos que, a principios de diciembre de 1840, sufrieron los diarios El Huracán y El Trueno, cuando en sus sedes se presentaron varios oficiales de ejército y amenazaron a sus redactores para que lo sucesivo se abstuvieran de escribir sobre el duque de la Victoria en la manera, a su entender despectiva, como hasta entonces lo habian hecho.

El ministro de la Gobernación, Manuel Cortina, se enfrentó a ambas situaciones, afirmando la libertad de imprenta consignada en el artículo $2^{\circ}$ de la Constitución. En la segunda, además, la libertad y seguridad personal, apostando para ello una custodia policial en sus redacciones. Seguidamente, a su instancia, el capitán general ordenó se practicaran las diligencias oportunas, pero al no encontrarse evidencias, se sobreseyó el caso. En la primera de las actuaciones, el jefe político fue desautorizado -y también sustituido en el cargo, que fue acumulado al del gobernador militar en manos en ese momento de José Grasses Saguí -, al ordenar el 18 de diciembre el titular de Gobernación a los delegados provinciales que no se inmiscuyeran en la labor de los promotores fiscales y les dejaran actuar por su propio impulso ${ }^{25}$.

De esta manera, las elecciones legislativas de marzo de 1841 se desarrollaron en un clima de amplia libertad de expresión. Así, retraídos los moderados, la prensa de su opinión se dedicó durante la campaña a ensalzar la labor realizada por los anteriores ejecutivos conservadores, descalificar a los progresistas por usurpar la voluntad nacional por medios insurreccionales $\mathrm{y}$, poniendo en entredicho la imparcialidad gubernativa, también al ejecutivo por recurrir a la coacción y al fraude electoral. Con la seguridad del triunfo electoral, los periódicos progresistas, por su parte, se involucraron poco en la campaña, pero sí pusieron de manifiesto la escisión interna de la formación, anticipándose al debate sobre la regencia. Por último, los republicanos, tras su avance en las elecciones municipales, aprovecharon la ocasión para difundir sin cortapisas su programa democrático, como lo hizo El Huracán.

La discusión que tras las elecciones se produjo en Cortes sobre la regencia, con una inclinación del Congreso a favor de la solución trinitaria y del Senado por la unitaria, se trasladó a la prensa. El Eco del Comercio, vinculado al progresismo radical encabezado por Joaquín María López, llevó a cabo importante campaña por la primera propuesta, y se vio respaldado por la prensa republicana. La Constitución, como ya lo hemos significado, lideró la defensa de la regencia en manos de Baldomero Espartero exclusivamente, a la que se sumó de forma muy tibia la prensa conservadora. Es de destacar, la participación en el debate en los medios de los militares ayacuchos y del propio duque de la Victoria ${ }^{26}$.

25 Para el desarrollo de la prensa durante el Ministerio-regencia hemos seguido: A.H.N., Consejos, 11.317/20, 11.318/111, 118 y 143, y 11.340/67; Demetrio Castro Alfin, Los males de la imprenta. Politica y libertad de prensa en una sociedad dual, op. cit., pp. 44-45; Pedro Gómez Aparicio, Historia del periodismo español...Vol. 1, pp. 275-278; Eugenio Hartzenbusch, Apuntes para un catálogo de periódicos madrileños desde el año de 1661 a 1870, op. cit., pp. 66-67; y Antonio Pirala Criado, Historia de la guerra civil y de los partidos liberal y carlista. Refundida y aumentada con la historia de la Regencia de Espartero, Madrid, Turner-Historia 16,1984, vol. VI, pp. 242-243.

26 Para la prensa de Madrid durante las elecciones y el debate sobre la regencia: Natividad Araque Hontangas, Las elecciones en el reinado de Isabel II: la Cámara baja, op. cit., pp. 255-262; José Segundo Flórez, (1845): Espartero. Historia de su vida militar y politica y los grandes sucesos 
Desde el comienzo en mayo de la regencia efectiva de este general, in crescendo se produjo una auténtica ofensiva, cuando no hostigamiento, contra éste, el régimen, el gobierno y su política por parte de la prensa, principalmente conservadora, pero también republicana. Para llevar esta acción se mantuvieron las principales cabeceras, se sustituyeron algunas de las recién creadas y se fundaron otras nuevas.

Así, en el caso de la opinión moderada, El Trueno, que sucumbió al concluir febrero, tuvo su continuidad formal en La Época, pero de contenido y actitud provocadora en El Cangrejo. Este periódico, subtitulado "Diario políticoburlesco...al nivel de las actuales circunstancias", lo fundó en abril Manuel Antonio de las Heras, conde de Sanafé, compañero de Luis González Bravo en la redacción de El Guirigay, que sufrió la misma metamorfosis al conservadurismo, defendiendo a María Cristina y sus amigos politicos y atacando de forma despiadada y denigrante al regente y sus principales colaboradores. Un mes antes de desaparecer este diario, en septiembre, apareció la revista semanal de política, ciencias y literatura titulada primero $E l$ Español y al poco $E l$ Conservador. Más seria que la anterior, esta publicación, que duró hasta febrero de 1842, contó Nicomedes Pastor Díaz, Joaquín Francisco Pacheco y Antonio Ríos Rosas como principales redactores.

Pues bien, mientras estos medios, sobre todo, El Correo Nacional, El Cangrejo y El Castellano, agitando al público de la capital, preparaban el terreno para el pronunciamiento retrógrado de octubre de 1841 , los de signo republicano lo hacian en sentido contrario. Como ocurriera con El Trueno, en la prensa republicana El Pueblo Soberano fue reemplazado desde mayo por El Regenerador, periódico que, contando como director con José Ordax Avecilla y con el lema "libertad, igualdad y fraternidad", era menos radical que El Huracán.

A esta prensa de política general se agregó otra político-militar que, en el proceso de reorganización del ejército con la terminación de la guerra carlista, tuvo un carácter más corporativo, aunque no sólo. Así, fue principalmente crítica con Baldomero Espartero y los generales ayacuchos El Grito del Ejército, revista de intereses militares que salió a la luz en mayo contando con Eduardo Perotte como principal redactor. A ella se adhirió después del pronunciamiento de octubre $E l$ Archivo Militar, periódico fundado en abril por el ex coronel Antonio Vallecillo.

Para hacer frente a esta amplia oposición de la prensa desde distintos ámbitos, el Gobierno de Antonio González intentó, por un lado, contrarrestarla y, por otro, combatirla. Para lo primero, ante el tibio apoyo proporcionado por el Eco del Comercio, se decidió crear una red medios del progresismo esparterista. Así, al mediocre diario La Constitución, que continuó desde octubre hasta final de año bajo la cabecera Revista del Progreso, desde agosto se contó un verdadero periódico digno de sus contrincantes, El Espectador. Este diario, que tuvo una primera etapa durante el trienio liberal, fue promovido por el presidente del ejecutivo y como en esa época por el general Evaristo San Miguel, y para la articulación del discurso del progresismo esparterista contó con una nómina de estimables redactores (entre ellos, Ángel Fernández de los Ríos). También siguió desde abril este discurso El Patriota que, manteniendo como principios la

contemporáneos, Madrid, Imprenta de D. Wenceslao Ayguals de Izco, vol. IV, pp. 11-71; y Carlos Marichal, La revolución liberal y los primeros partidos políticos en España: 1834-1844, Madrid, Cátedra, 1980, pp. 212-215. 
Constitución de 1837, Isabel II y la independencia nacional, en esta segunda etapa los defendía desde la perspectiva ayacucha ${ }^{27}$.

Con estos rotativos, además de los oficiales, se buscaba difundir el ideario y la politica del progresismo esparterista, así como reducir la influencia de la prensa de la oposición. Para frenarla se recurrió a un estricto control de sus artículos que, en una primera etapa, se llevó a cabo solo bajo "el impulso propio" de los promotores fiscales. Fueron particularmente enérgicos. Otra cosa no se puede decir del aumento desorbitado de las denuncias que se produjo desde que Baldomero Espartero fue nombrado regente. Hasta entonces, durante los primeros cuatro meses de 1841, como ya hemos significado el número de denuncias fue relativamente corto, solo 16. Desde entonces, durante los ocho meses siguientes, hasta la conclusión del año, la cifra se disparó hasta alcanzar las 71 denuncias. Así, durante 1841 fueron denunciados 87 artículos frente a 53 en 1840 y 77 en 1842 .

Pormenorizando un poco, en primer lugar, es de reseñar a lo largo de 1841 brillan por su ausencia las denuncias efectuadas a la prensa progresista. Solo 5: 3 en los primeros cuatro meses y 2 en los ocho siguientes, que recaen en 4 en el Eco del Comercio y 1 en el Eco de la Milicia. Por lo tanto, las denuncias recaen en los rotativos conservadores y republicanos, principalmente en los primeros. Así, a lo largo del año fueron denunciados 56 artículos de periódicos de opinión moderada, 7 en los primeros cuatro meses, 49 después. La cifra total de las denuncias de los escritos de las publicaciones republicanas situada en $15-4$ hasta mayo y 11 hasta el final de año-debe elevarse porque muchas de las hojas volantes denunciadas (8) son de su espectro ideológico. Los periódicos que sufrieron más denuncias fueron El Cangrejo con 24 (23 desde mayo) y El Correo Nacional con 23 (20 desde mayo). Les siguen El Huracán con 13 (10 desde mayo) y después las distintas hojas volantes con 8 (7 desde mayo).

En segundo lugar, en cuanto al recorrido de las denuncias, debe significarse que los jurados de la acusación durante los primeros cuatro meses fueron bastante proclives a fallar en favor de la formación de causa -11 de los 16 artículos denunciados (69\%)- mientras que los siguientes ocho meses fueron algo más reticentes, 43 de 71 (60\%). No hay muchas diferencias entre los periódicos de uno u otro signo político. Así se decidió seguir con el proceso con 34 de 56 (60\%) de los artículos denunciados de la prensa conservadora (27 de 49 desde mayo, 55\%) y con 10 de 15 (66\%) de escritos denunciados de los medios republicanos (7 de 11 desde mayo, 63\%). Finalmente, solo con 2 de los artículos

27 El mapa de los periódicos madrileños de 1841 lo hemos bosquejado siguiendo a: José Segundo Flórez, Espartero. Historia de su vida militar y politica y los grandes sucesos contemporáneos, op. cit., vol. IV, pp. 191-193 y 226-235; Pedro Gómez Aparicio, Historia del periodismo español... Vol. 1, pp. 278-284; Eugenio Hartzenbusch, Apuntes para un catálogo de periódicos madrileños desde el año de 1661 a 1870, op. cit., pp. 66-73; y María Cruz Seoane y María Dolores Saiz, Historia del periodismo en España. 2. El siglo XIX, op. cit., pp. 183-187. Las referencias de la prensa político-militar en: Jesús Cantera Montenegro, "Ejército y sociedad: imagen social del ejército" en Hugo O’Donnell y Duque de Estrada (dir.): Historia militar de España. IV Edad Contemporánea. I. El siglo XIX, Madrid, Ministerio de Defensa, 2015, pp. 434-436; y E. Christiansen, Los origenes del poder militar en España, 1800-1854, Madrid, Aguilar, 1974, pp. 184-186. 
del Eco del Comercio publicados a partir de mayo el jurado decidió seguir adelante con la causa ${ }^{28}$.

Pues bien, a pesar de que los jurados de la calificación con las penas impuestas fueran marcando el camino para la desaparición en octubre de $\mathrm{El}$ Cangrejo, en enero de 1842 de El Huracán y después ya en junio de El Correo Nacional, los promotores fiscales trasladaron al Gobierno, a través del Ministerio de Gracia y Justicia, las carencias y relajaciones que a su juicio observaban en la aplicación de la normativa de imprenta. En primer lugar, señalaban que en ellos recaía un exceso de responsabilidad ("eran los únicos que presentaban la cara") y no contaban con un respaldo y unas directrices gubernativas. En segundo lugar, observaban una cierta connivencia y parcialidad del Ayuntamiento de Madrid, particularmente de su alcalde, con la prensa de carácter republicano, al no comunicarles las fechas de los sorteos de los jueces y al posponer en el tiempo la celebración de los juicios. En tercer lugar, achacaban la impunidad en la que quedaban algunos artículos denunciados a la escasa formación de los jueces de hecho (que para el promotor fiscal José García de los Ríos se debía a la pequeña cuota de contribución directa exigida) y a la falta de rectificación de sus listas desde 1839. En cuarto lugar, mostraban las dificultades que tenían para hacer frente a algunas acciones de los periódicos: intimidaciones y coacciones a los jurados; sustitución de periódicos suprimidos por hojas volantes; ser editor responsable de varios periódicos a la vez y, sobre todo, mantenerse como editor responsable, a pesar de estar encarcelado o de haber declarado el jurado la formación de causa.

Los promotores fiscales entendian que en estos casos los editores debían estar inhabilitados y, contando con el dictamen favorable de Tribunal Supremo, así lo recogió la orden de 9 de septiembre. A partir de entonces se impediría la circulación de cualquier periódico (también impresos y hojas sueltas) cuyo editor responsable estuviera procesado o encarcelado, en tanto no fuera reemplazado por otro que reuniera las cualidades exigidas. Además, se volvía hacer intervenir a los jefes politicos, encargándoles vigilar la observancia de la legislación especial de imprenta. Por eso, coetáneamente, se les impelió a que, en sus respectivas provincias, se procediera a la actualización de las listas de los jurados antes del comienzo del siguiente año.

La aplicación de esta nueva disposición agravó sobremanera los problemas que en Madrid sufrian los periódicos reiteradamente denunciados, como El Cangrejo, El Correo Nacional o El Huracán, ya que los distintos fallos condenatorios recibidos les obligaban, además de a satisfacer las multas correspondientes, a sustituir a los editores. A partir de este momento su margen de maniobra era mucho menor y, por eso, cuando el jurado de la acusación declaró la formación de causa a alguno de sus artículos, los tres diarios vieron momentáneamente suspendida su publicación. El Cangrejo no pudo hacer frente a la presión y publicó su último número el 6 de octubre. El Correo Nacional no lo pasó bien y por eso puso un anuncio solicitando editores responsables y requirió al Ministerio de la Gobernación que se le aplicara la censura previa, pero lo que

28 Los datos sobre los tribunales en: A.V.M, Secretaría, 4/163/6; y Mercedes Cabrera, Antonio Elorza, Javier Valero y Matilde Vázquez, "Datos para el estudio cuantitativo de la prensa (18501875)", en Manuel Tuñón de Lara, Prensa y sociedad en España, 1820-1936, op. cit., pp. 66-75 y 81-82. 
verdaderamente le afectó fue el fallido pronunciamiento conservador de este mes, ya que involucrado muy directamente, supuso para Andrés Borrego la formación de una causa criminal, el destierro y la pérdida de la propiedad del periódico.

A la represión que acompañó al sojuzgamiento de esta insurrección y la subsiguiente movilización radical de Barcelona, se sumó un control mucho más estricto sobre la prensa. Así, "revelando estos acontecimientos -señalaba el ministro de la Gobernación, el general ayacucho Facundo Infante- el pernicioso influjo que sobre la tranquilidad pública ejercian ciertos impresos", el 22 de diciembre ordenaba a los jefes políticos que suspendieran la circulación de todo periódico, hoja volante o escrito en que se atacara la Constitución política de la Monarquía o se excitare la realización de cualquier otro sistema de gobierno ${ }^{29}$.

Más que por el influjo pernicioso, el mayor control arbitrado sobre la prensa se debió al aumento de la crítica y antagonismo al ejecutivo. Derivó de la disconformidad, sobre todo, con la forma autoritaria y exclusivamente castrense de resolver los problemas de orden público, también con la persistente corrupción y malversación de los fondos públicos y con la inclinación centralizadora y censitaria muy presente en la propuesta de organización de la administración territorial. La discrepancia en estos asuntos ahondó la fractura entre las tendencias del progresismo hasta el punto de lograr que en mayo de 1842 prosperara una moción censura al gabinete de Antonio González. Y la división de esta fuerza liberal y la debilidad parlamentaria del Gobierno sustituto del general José Ramón Rodil fue aprovechada por los moderados y republicanos para incrementar la oposición a través de sus medios de comunicación.

Fracasado el pronunciamiento de octubre, para esta actuación la opinión conservadora contó con las cabeceras ya consolidadas como con las que inmediatamente fueron apareciendo. Entre éstas, en primer lugar, La Postada, la continuación desde enero por parte del conde de Sanafé de El Cangrejo, con los mismos contenidos y carácter sarcástico displicente. En segundo lugar, con el respaldo financiero e ideario conservador del entorno del exilio parisino de María Cristina, en junio reemplazando a El Correo Nacional surgió El Heraldo. El excesivo personalismo que al parecer imperó en esta publicación durante la dirección de Luis José Sartorius, impelió a alguno de sus redactores, como Antonio Ríos Rosas, Nicomedes Pastor Díaz y Gabriel García Tassara, a separarse y fundar en noviembre, en tercer lugar, $\mathrm{El} \mathrm{Sol,} \mathrm{periódico} \mathrm{moderado} \mathrm{más} \mathrm{liberal.}$ En el otro extremo, en cuarto lugar, se encontraban La Cruz, periódico de religión, de literatura y política, El Trono, periódico político, literario y religioso, y El Reparador, que era la continuación de La Voz de la Religión, publicada entre 1837-1841.

Por su parte, el conglomerado republicano, que había visto reafirmadas sus potencialidades en las elecciones municipales de diciembre de 1841, recuperó, después de un final de año un tanto complicado, el número de sus cabeceras. Así, a El Regenerador, que no pudo superar el verano de este año, a principios de

${ }_{29}$ Para este cambio de política: A.H.N., Consejos, $11.317(1) / 2,4,13,14$ y 15; 11.319/39 y 11.340/67 y 69; Concepción de Castro, Romanticismo, periodismo y política. Andrés Borrego, op. cit., pp. 212-213; Demetrio Castro Alfin, Los males de la imprenta. Politica y libertad de prensa en una sociedad dual, op. cit., pp. 50-52; y Pedro Gómez Aparicio, Historia del periodismo español, op. cit., vol. 1, pp. 282-286. 
1842, como ya hemos visto, se sumó la suspensión de El Huracán. Pero, mientras éste apenas si pudo dar señales de vida mediante hojas sueltas para enlazar con una nueva edición en marzo de 1843, aquél tuvo su continuidad en enero de 1842 con El Argos. A partir de entonces se produjo el resurgir de la prensa republicana madrileña, primero, con El Peninsular, subtitulado diario del pueblo, pero más comedido que El Huracán, y dirigido por el diputado Antonio Garcia Uzal, y, desde abril, con la Guindilla, periódico satírico-político-burlesco, dirigido por el prolifico folletinista Wenceslao Ayguals de Izco.

En el espectro progresista, el Eco del Comercio, con el cambio de propietarios a finales de agosto de 1842, se supeditó a un poderoso grupo de intereses vinculado al infante Francisco (que perseguía la declaración inmediata de la mayoría de edad de Isabel II y su matrimonio con el hijo de éste) y se distanció del grupo radical y significó en la oposición al esparterismo gobernante. También aquí y ubicados en un liberalismo bastante contenido, se acabaron encontrando desde julio de 1842 El Español Independiente, que no lo había estado cuando apareció en diciembre de 1841 como El Independiente, y, desde diciembre de 1842, El Pabellón Español. De esta manera los periódicos adictos a la regencia del duque de la Victoria y a su forma de gobernar se reducian a los citados $E l$ Espectador y El Patriota, y desde agosto de 1842 La Iberia, dirigida por Pablo Alonso Avecilla y El Centinela, del que no tenemos datos ${ }^{30}$.

No parece que esta prensa afin fuera particularmente brillante en la defensa de la actuación política de los Gobiernos formados por Baldomero Espartero, pero tampoco, todo lo indica, que caracterizara el papel de oposición de la prensa disidente. No cuestionamos la tarea crítica, que la hubo, y resulta imprescindible en un régimen representativo, más aún cuando en el mismo se produce una deriva autoritaria, como la que se estaba generando bajo la regencia de ese general. $\mathrm{Ni}$ tampoco ponemos en entredicho las estrategias seguidas por los medios para soslayar las trabas normativas y seguir realizando su labor periodística, como hicieron El Huracán y El Peninsular para continuar publicando sin un editor responsable: el primero sustituyó el diario por hojas volantes; el segundo quiso ser más ingenioso el reemplazó el título por el artículo constitucional que consignaba la libertad de prensa ("Todos los EspañoLes PuedEN Imprimir y publicar libremeNte SUs ideas, sin previa censura, con sujeción a Las leyes. ARt. $2^{\circ}$ de la Constitución").

Lo que escapaba a cualquier lógica fue la campaña abierta de acoso y derribo del regente y sus amigos politicos, en la que se perdió todo atisbo de compostura y respeto, recurriendo asiduamente a la caricatura, al mote, a la mofa, befa y escarnio, y utilizando un lenguaje violento, insultante y soez. Así lo plasmaba Benito Pérez Galdós, uno de los mejores retratistas de la realidad española decimonónica, en el episodio nacional titulado Los Ayacuchos: “(...) Tan aburrido estoy, que suelo buscar distracción en la lectura de los periodicuchos que difaman al Gobierno, al Regente y a todo lo que significa jerarquía $y$

30 Para el desarrollo de la prensa madrileña en 1842: Demetrio Castro Alfin, Los males de la imprenta. Politica y libertad de prensa en una sociedad dual, op. cit., pp. 50-53; Pedro Gómez Aparicio, Historia del periodismo español, op. cit., vol. 1, pp. 286-293; Eugenio Hartzenbusch, Apuntes para un catálogo de periódicos madrileños desde el año de 1661 a 1870, op. cit., pp. 73-81; Carlos Marichal, La revolución liberal y los primeros partidos politicos en España: 1834-1844, op. cit., pp. 239-240; y María Cruz Seoane y María Dolores Saiz, Historia del periodismo en España. 2. El siglo XIX, op. cit., pp.185-190. 
autoridad, y más me seducen y divierten cuanto más groseros y estúpidos disparates escriben. La Guindilla trae un muñeco que imita la persona de Rodil, con su cara de histrión, su rasgada boca y sus bucles sobre las 68 sienes. Le representa bailando el zapateado, y pone en sus labios unas ridículas décimas con glosa. Adulando los bajos gustos de mucha gente, el papel llama Bobil al presidente del Consejo, y a todas las figuras culminantes de la Nación las señala con soeces motes. Almodóvar es Poenco; Mendizábal, Mamacallos; Calatrava, La Tía Ramona, y Argüelles, Pinchaúvas". Pues bien, con esta actuación desmedida, en la que descollaron los periódicos ideológicamente antagónicos como la referida Guindilla y La Posdata, para Ángel Fernández de los Ríos se escribió una de las páginas más bochornosas e indignas de la historia del periodismo español, en la que, según F. Sainz, hubo "libelos en vez de periódicos, pasquines incendiarios más que órganos de ilustración ${ }^{31 "}$ ".

Para hacer frente a esta ofensiva de los medios los gobiernos esparteristas no tomaron medidas excepcionales. Simplemente, por un lado, aplicaron la legislación y, por otro, propusieron reformar la normativa sobre libertad de imprenta. Para el primer cometido el ministro de la Gobernación del ejecutivo de José Ramón Rodil, Mariano Torres Solanot, sí solicitó a los jefes políticos que, para hacer frente a las demasias de la prensa, no recurrieran al mismo medio para responder a los insultos y calumnias ni entraran en polémicas con los editores y, en su lugar, activaran el celo de los promotores fiscales para no permitir el minimo resquicio a la impunidad. A éstos no parece que fuera muy necesario adoctrinarles, ya lo estaban. Así lo atestiguan las 77 denuncias presentadas a lo largo de 1842, que sitúan a este año en el ranking justo después del anterior, que fue cuando las denuncias alcanzaron la cima. Como entonces, en 1842 las denuncias se concentraron en la prensa conservadora y republicana, respectivamente, con 40 y 21 , pero debiendo sumar a esta última cifra la mayoría de las hojas sueltas, 7. El grueso de las denuncias recaen, de aquella, en $L a$ Posdata con 19 y, de ésta, en El Peninsular con 17. Obviamente, no hay artículo alguno denunciado de la prensa adicta y escasean los de la progresista, solo 5 .

En cuanto al recorrido de las denuncias, los tribunales de la acusación fallaron a favor de la formación de causa en 35 de los 77 artículos denunciados (el 45\%). De ellos 17 eran de la prensa conservadora (de 40; el 42,5\%), 10 de la republicana (de 21; el 47,6\%) y 4 de la progresista (de 5; el 80\%). Pues bien, a pesar de que, con relación a 1841 el porcentaje de los artículos denunciados que prosperaron fue mucho menor, los gobiernos ni tomaron acciones drásticas ni suspendieron ningún diario. Sí se introdujeron algunas correcciones como la realizada por la ley de 9 de julio que ampliaba la definición formal de lo que se consideraba un periódico para poder incluir a los folletos: "Se entenderá -se decia- por periódico, para los efectos legales, todo impreso que se publique en épocas y plazos determinados o indeterminados con nombre o sin él, y no exceda

31 Para esta actuación de la prensa: A.V.M., Corregimiento 1/155/49; Ángel Fernández de los Ríos, Estudio histórico de las luchas politicas en la España del siglo XIX, Madrid, English y Gras, 1879-1880, vol. I., pp. 342-346; José Segundo Flórez, Espartero. Historia de su vida militar y política y los grandes sucesos contemporáneos, op. cit., vol. IV, pp. 622-633 y 680-685; Benito Pérez Galdós, Los Ayacuchos, Madrid, Establecimiento Tipográfico de la Viuda e Hijos de Tello, 1900, p. 67-68; y F. Sainz, Historia de la Milicia Nacional desde la creación en el año 1820 hasta el desarme general en 1844, Madrid, Imprenta de Benito Hortelano y Compañía, 1845, vol. II, pp. 1.004 y 1029 . 
de seis pliegos de impresión de la marca de papel sellado". También, dada la relativa impunidad de la que disfrutaba la prensa por la benevolencia de los jurados, el ejecutivo de José Ramón Rodil el 10 de octubre nombró una comisión, presidida por el egregio Manuel José Quintana, para reformular la legislación de imprenta, "refundiendo todas las disposiciones anteriores dispersas e introduciendo las mejoras que la experiencia reconocia necesarias y que reclamaba el abuso de la prensa ${ }^{32 "}$.

Pues bien, a pesar de la falta de concreción y de haber sido la exigencia de la reforma de la normativa de imprenta un lugar recurrente durante el régimen constitucional de 1837, en esta ocasión aunó a periódicos de distinto signo para impedir lo que estimaban iba a ser un atropello a libre ejercicio de la libertad de prensa. El principal promotor fue el diario conservador El Heraldo, pero muy pronto contó con el concurso del Eco del Comercio que, con una trayectoria en pos de la defensa unitaria de los medios por este derecho constitucional, aportó las pautas organizativas. Parece que favoreció el acercamiento el conflicto laboral con los cajistas que, afectando a casi todas las empresas editoras de prensa de Madrid, a las de esos dos periódicos les ocasionó grandes dificultades para poder sacar a la calle sus cabeceras durante la segunda quincena de julio. Obviamente, también favoreció la relación el mencionado cambio en la propiedad del Eco del Comercio.

El entendimiento entre estos periódicos se extendió a diez más de los publicados en la capital (El Peninsular, El Castellano, La Posdata, El Trono, El Católico, El Corresponsal, la Guindilla, El Español Independiente, Revista de Madrid y Revista de España y del Extranjero), que fueron los que, junto a los anteriores, el 31 de octubre firmaron la "declaración de la prensa independiente". Pues bien, si el Eco del Comercio fue el que propuso a los estaban al frente de "las redacciones periodísticas, sin exclusión de colores ni banderías, la reunión amiga y fraternal", El Heraldo se encargó de otorgarle el contenido ideológico. Se justificaba la coalición por la represión de la libertad de prensa ejercida por los Gobiernos de Baldomero Espartero en la aplicación estricta de la legislación, incomparable con la de cualquier ejecutivo anterior, en la persecución llevada a cabo por los agentes gubernativos frente -se subrayaba- a la serena e imparcial firmeza de los jurados, en la falta de prevención e impunidad en que quedaban los autores de los atentados sufridos por diferentes diarios, en el carácter violento, injusto y ofensivo a la moralidad de los escritores públicos de las órdenes expedidas y en la tentativa de reforma de la legislación imprenta contraria a los principios constitucionales. De acuerdo con ello se aunaban para defender, exclusivamente por medios lícitos, la libertad de imprenta, y la seguridad y libertad individual conforme a lo establecido en la Constitución y desarrollado en las leyes, y también para impedir la no prorrogación de la menor edad de la reina.

La contradicción existente entre esta declaración y los idearios tan dispares de las publicaciones firmantes, como el absolutista de El Católico (a pesar de

32 Para la actuación gubernativa: A.V.M., Secretaría 4/163/7; Mercedes Cabrera, Antonio Elorza, Javier Valero y Matilde Vázquez, "Datos para el estudio cuantitativo de la prensa (18501875)", en Manuel Tuñón de Lara, Prensa y sociedad en España, 1820-1936, op. cit., pp. 67-68 y 73-74; y Mariano Torres Solanot, Memoria del Ministerio de la Gobernación de la Península, Madrid, Imprenta Nacional, 1843, pp. 5-6. 
contar con un voto particular en el último de los puntos) o el republicano de $E l$ Peninsular, acabaron casi reduciendo a la oposición al progresismo gobernante el único punto compartido. De ahí que Ángel Fernández de los Ríos considerara a esta coalición de la prensa una especie de añagaza, propiciada por los rotativos moderados, principalmente El Heraldo, para sentar las bases de una coalición política antiesparterista. Algo que favoreció sobremanera su continuidad fue la forma tan draconiana empleada por el regente y la cúspide militar para sofocar a principios de diciembre la sublevación republicana de la ciudad condal. De ahí que al regreso a Madrid de Baldomero Espartero se publicaran en algunos de los diarios coaligados los artículos constitucionales a los que remitía el texto que los había aunado y una nueva declaración en contra del tratado comercial con Gran Bretaña, que incorporaba a la asociación a tres nuevos periódicos, El Sol, El Reparador y El Pabellón Español.

También coadyuvaron a mantener y reactivar esta coalición de la prensa madrileña actuaciones como las del promotor fiscal José García de los Ríos, que solicitó la pena de garrote vil en el proceso que a su entender debía instruirse contra el abogado de El Peninsular, Eusebio Asquerino, por haber proferido en una vista del jurado de la causa a un artículo de este diario palabras altamente ofensivas a la dignidad del regente. La acción de la coalición y el Colegio de Abogados de Madrid impidieron que tal atropello pudiera prosperar, pero no que el editor de ese diario, Demetrio Monasterio, fuera condenado a cuatro años de prisión al ser calificado lo publicado por el tribunal sedicioso en segundo grado, $\mathrm{y}$ que el diario desapareciera a mediados de abril de $1843^{33}$.

A la censura casi generalizada de la prensa europea al ejecutivo esparterista por su actuación en Barcelona, se sumó la de la española y, particularmente, la capitalina, que a comienzos de ese año intensificó sus críticas por la disolución de las Cortes para soslayar el debate parlamentario y por el incremento del control gubernativo para intentar acallar a los medios de la oposición. La orden de 10 de enero que lo contemplaba, culpaba sin ambages a "la desenfrenada licencia y extravíos de la imprenta periódica" de la convulsión social y, para neutralizarla, requería a los delegados gubernativos que suspendieran la circulación de cualquier escrito que con motivo fundado se considerara pudiera alterar la tranquilidad pública, y se procediera a su denuncia en el término de doce horas, sin que los fallos contrarios de los jurados -se subrayaba- les hicieran desistir de su acción. Además, complementando esta actuación y la labor de la comisión de octubre, a principios de marzo se nombró otra, presidida por José María Calatrava, indicada a establecer las medidas indispensables y urgentes que pudieran frenar los excesos y desvarios de la prensa. Y, por último, se reorganizaban las sesiones de los juicios de los jurados de calificación para impedir las alteraciones del orden por parte del público concurrente.

Con estas disposiciones, por los menos en Madrid, no cambiaron mucho las cosas. Es verdad que, durante los tres primeros meses del año, hasta la

33 Para la formación de la coalición de la prensa madrileña: A.H.N., Consejos 11.341(1)/11 Eco del Comercio, 12.07, 21 y 25.10, 1.11.1842 y 1 y 3.01.1843; El Heraldo, 25 y 29.10 y 2.11.1842; Demetrio Castro Alfin, Los males de la imprenta. Politica y libertad de prensa en una sociedad dual, op. cit., pp. 53-54; Ángel Fernández de los Ríos, Estudio histórico de las luchas politicas en la España del siglo XIX, op. cit., vol. I., pp.346-348; José Segundo Flórez, Espartero. Historia de su vida militar y politica y los grandes sucesos contemporáneos, op. cit., vol. IV, pp. 680-689 y 795797; y Pedro Gómez Aparicio, Historia del periodismo español, op. cit., vol. 1, pp. 293-299. 
celebración de las elecciones, bajo el mandato de Alfonso Escalante como jefe político se aumentó de forma importante el número de denuncias: se pasó de las 14 que hubo en 1841 y 16 en 1842 a 27. Pero de ellas como era habitual los jurados fallaron a favor de la formación de causa solo en 10 de ellas. De ahí que periódicos esparteristas como El Patriota y El Espectador, a pesar de declararse liberales, propusieran medidas anticonstitucionales y autoritarias para frenar el apoyo que a su juicio esos tribunales prestaban a la prensa de la oposición ${ }^{34}$.

De esta manera, durante las elecciones legislativas se reafirmó la asociación de la prensa de la capital y se dieron pasos ya firmes para el desarrollo de coaliciones politicas antiesparteristas. El partido moderado, con apoyo de $E l$ Heraldo, fue su principal impulsor y lo hizo acompañándose de un discurso de plena aceptación de la Constitución y régimen constitucional de 1837. Reaparecía menos reaccionario y más liberal-conservador para intentar atraerse a las bases sociales del partido progresista, que estaban totalmente confundidas ante la división de esta formación. Así, junto a los ministeriales, los ayacuchos, se presentaron a los comicios los progresistas radicales liderados por Joaquín María López, los legales encabezados por Manuel Cortina, que fue dentro del progresismo el promotor de las candidaturas mixtas, y la agrupación a cuyo frente estaba Salustiano Olózaga. Además, el periódico que había sido principal referente de esta fuerza politica, el Eco de Comercio, al parecer apoyaba a esta última facción, pero sobre todo a los francisquistas, seguidores del infante Francisco. También los republicanos estaban escindidos entre los antiesparteristas que, respaldados por El Peninsular y la Guindilla, eran más conciliadores con los moderados y la Monarquía constitucional, y los que, teniendo a El Huracán como principal medio de expresión, más que esparteristas eran anticonservadores y republicanos, y querian evitar el cisma con el cuerpo popular de la milicia nacional.

Fue el propio duque de la Victoria el que limó las diferencias de la oposición y de su prensa al publicar el 6 de febrero un manifiesto que, siendo una clara extralimitación constitucional, se identificaba de forma parcial con el progresismo ministerial y reivindicaba a su persona y labor militar y civil, confiriendo a las elecciones el carácter plebiscitario. Pues bien, al no logar él y sus amigos el suficiente respaldo parlamentario, el 9 de mayo confió el Gobierno al progresismo radical liderado por Joaquín María López.

Pero, al discrepar totalmente del programa politico e interpretación parlamentaria que éste realizaba de la Constitución, diez dias después le aceptó la dimisión. A partir de entonces la actuación de Baldomero Espartero como regente fue una réplica casi exacta de la seguida por María Cristina en el tiempo inmediato a las movilizaciones de 1836 y 1840, produciendo idénticos resultados ${ }^{35}$.

34 Para esta acción gubernativa sobre la prensa: A.H.N., Consejos, 11330/34 y 11341(1)/11; A.V.M, Secretaría, 4/163/7; y José Segundo Flórez, Espartero. Historia de su vida militar y politica y los grandes sucesos contemporáneos, op. cit., vol. IV, pp. 813-815.

35 Para la prensa madrileña durante las elecciones: Natividad Araque Hontangas, Las elecciones en el reinado de Isabel II: la Cámara baja, op. cit., pp. 279-287; Pedro Díaz Marín, La Monarquía tutelada. El progresismo durante la Regencia de Espartero, Alicante, Universidad d'Alacant, 2015, pp. 346-391; y Carlos Marichal, La revolución liberal y los primeros partidos políticos en España: 1834-1844, op. cit., pp. 245-249. 
Volvió a refugiarse en la adicta cámara alta, encargando la formación de Gobierno al presidente de la misma, Álvaro Gómez Becerra. Además, ante la censura de la actuación y respaldo póstumo conferido por el Congreso al programa y gabinete anterior, se decretó la suspensión de sus sesiones. Inmediatamente la prensa coaligada desató una campaña contra el regente y su camarilla ayacucha, tildándoles de despóticos, y que quiso significar por algunos de sus diarios, recogiendo en su primera página los artículos 2 , 73 y 74 de la Constitución, referidos a la libertad de prensa y a la necesaria aprobación de los presupuestos por las Cortes, y por otros, encabezando sus editoriales con el eslogan, "Unión de todos los españoles -guerra abierta y sin tregua a los angloayacuchos- ¡Dios salve al país y a la reina!". Esta última frase del famoso discurso de Salustiano Olózaga, que marcaba la ruptura del Congreso con el regente, los republicanos la sustituían por iSálvese el pueblo soberano!

Las repuestas gubernativas dadas a las oposiciones periodística y parlamentaria supusieron un punto de no retorno. Otra cosa no podía producir la orden del nuevo titular de la Gobernación, Pedro Gómez de la Serna, a los jefes políticos por la que, al tiempo que manifestaba que el propósito del Ministerio era conferir la máxima latitud al ejercicio de la libertad de imprenta, les señalaba que aplicaran "el condigno castigo a aquellos escritores que, olvidando lo que a su misma patria debian, excitaran con sus publicaciones el desorden, atacaran la ley fundamental, la religión y la moral o faltaren el respeto debido al Trono y al jefe de Estado que lo representa". Pero lo que superaba con creces a esta disposición y taxativamente marcaba un antes y un después fue el decreto de disolución conferido el 26 de mayo al ejecutivo recién nombrado.

Por eso, a continuación, se produjo un movimiento insurreccional antiesparterista en las principales ciudades que, canalizado en juntas, primeramente, contó con las fuerzas más afines al líder progresista radical y las republicanas, después, las del progresismo legal y las moderadas y, finalmente, con oficiales del ejército de esta tendencia política, agrupados en la Orden Militar Española. Pues bien, Madrid, salvaguardado por la milicia nacional, no se sumó a la movilización, pero sí lo hizo la mayoría de su prensa, la coaligada.

Así, los periódicos que formaban parte de esta asociación continuaron con su campaña de denigración de la persona, obra y amigos de Baldomero Espartero y de identificación del régimen bajo su regencia con la tiranía, el despotismo o como "la historia de un ominoso mando". Pero, además, dado que estos diarios contaban con lectores dentro y fuera de la capital, tuvieron un papel importante en la información y difusión de la insurrección, ya en sus páginas se recogían crónicas pormenorizadas de los levantamientos de las distintas ciudades y manifiestos de los sublevados y de la progresiva pérdida de autoridad del regente y del progresismo esparterista. La publicación de estas noticias fue factible porque, el desconcierto y la incertidumbre provocadas por la insubordinación, redujeron sobremanera las denuncias realizadas por los promotores fiscales: solo 9 durante los meses de junio y julio. De esta manera, a pesar de que los jurados de la acusación fueran menos magnánimos (de los artículos denunciados se falló a favor de la formación de causa en 6 de ellos), los periodistas disfrutaron de una gran libertad en el ejercicio de su profesión.

En este contexto es donde, a nuestro entender, debe situarse la estrambótica orden de 1 de julio por la que desde entonces no se admitirian a franqueo, ni tendrian curso en la administración general de Correos otros periódicos que la 
Gaceta de Madrid y los esparteristas El Espectador, El Patriota y El Centinella. Y también bajo esa realidad se puede comprender que, un cuerpo tan adicto a Baldomero Espartero como la milicia nacional de Madrid, se extralimitara e individuos de la misma conminaran violentamente a Modesto Lafuente, editor que había sido de Fray Gerundio, y al del Eco del Comercio para que dejaran de escribir en el sentido que lo estaban haciendo o que los custodiaban la Casa de Correos se abstuvieran de intervenir contra los que proferian insultos y amenazas a los que leían este último diario en el patio de esta oficina.

Esto no era más que la expresión de la impotencia y la rabia de esta milicia ciudadana que, finalmente el 24 de julio, tuvo que claudicar ante las fuerzas militares insurreccionadas comandadas por el general Ramón $\mathrm{M}^{\mathrm{a}}$ Narváez, terminando seguidamente con la regencia del duque de la Victoria ${ }^{36}$. En esta conclusión tuvo un papel notorio la coalición periodística, ya que contribuyó a aunar las distintas voluntades de todo el espectro de fuerzas políticas y de la opinión pública contra Baldomero Espartero. Fue clave para la enajenación de los apoyos y pérdida de legitimidad del regente, para la difusión y ampliación de las adhesiones a la insubordinación y para la construcción de una coalición política antiesparterista, pero no para definir un proyecto alternativo.

\section{EPÍLOGO: HACIA LA SUPRESIÓN DEL JURADO.}

Con el triunfo de la movilización antiesparterista, si no todas, sí las principales fuerzas liberales que la habian animado, progresistas y moderados, mantuvieron durante un tiempo los compromisos adquiridos en aquella. Estos se sustentaron, fundamentalmente, en la instauración de un Gobierno provisional presidido por Joaquín María López y el desarrollo de una acción política cuyos principales cometidos eran: la canalización de aquellas juntas que aceptaban su autoridad en las Diputaciones provinciales, que seguidamente se elegirian, y el sojuzgamiento de aquellos otras, como las de Aragón y Cataluña, que auspiciaban la creación de una junta central; y la celebración de elecciones generales para que, con la proclamación de la mayoría de edad de Isabel II y juramento constitucional, se abriera una nueva etapa en la Monarquía constitucional.

Durante la campaña y desarrollo de estos comicios se disfrutó, como nunca hasta entonces a lo largo del régimen constitucional de 1837, de una plena libertad de imprenta. Para ello el ejecutivo, que contaba con Fermín Caballero como responsable de la cartera de Gobernación, puso en libertad a todos los presos y confinados por delitos de imprenta, así como a todos los procesados, sobreseyéndose sus causas. Además, permitió, sin limitación alguna, la libre circulación de todos los periódicos que se publicaran y, recordando la obligación que constitucionalmente correspondía al Gobierno de

36 Para este tramo final de la regencia de Baldomero Espartero y el papel de la coalición periodista: A.H.N., Consejos, 11.330/34; A.V.M, Secretaria, 4/163/7 y Corregimiento, 2/288/32, 33 y 34; Francisco Cánovas Sánchez, El partido moderado, Madrid, Centro de Estudios Constitucionales, 1982, pp. 4-6; Demetrio Castro Alfín, Los males de la imprenta. Politica y libertad de prensa en una sociedad dual, op. cit., p. 54; José Segundo Flórez, Espartero. Historia de su vida militar y politica y los grandes sucesos contemporáneos, op. cit., vol. IV, pp. 889 y 947-949; Pedro Gómez Aparicio, Historia del periodismo español, op. cit., vol. 1, pp. 299-304; y Carlos Marichal, La revolución liberal y los primeros partidos politicos en España: 1834-1844, op. cit., pp. 250-254. 
proteger y garantizar a todos los ciudadanos el derecho a expresar y publicar libremente sus opiniones por medio de la imprenta, previno a los jefes politicos para que no traspasaran con gestiones indebidas la linea de las facultades que las leyes les concedian en esta materia e inmiscuyeran en las tareas propias del ámbito judicial.

De esta manera lo hicieron, por lo menos en Madrid, los jefes politicos que sucedieron hasta las elecciones, Javier Quinto y Juan Antonio Garnica. Con ellos las denuncias brillaron por su ausencia. Es verdad que número de rotativos después de la movilización del verano era menor. Sólo los periódicos de orientación conservadora mantuvieron sus cabeceras e, incluso, las aumentaron, primero, entre octubre de 1843 y febrero de 1844, con El Mundo $\mathrm{y}$, después, desde la última fecha con el periódico reaccionario dirigido por Jaime Balmes, El Pensamiento de la Nación. Los de la tendencia liberal progresista siguieron en sus horas bajas, ya que solo persistieron, con una interrupción entre febrero y mayo de 1844, el Eco del Comercio y El Espectador, porque El Bien del País tuvo una vida muy efímera, sólo desde mediados de agosto de 1843 a finales de enero de 1844. Tampoco les iba muy bien a los diarios de las corrientes republicanas porque la desaparición en julio de 1843 de la Guindilla y El Huracán, apenas si pudo ser cubierta con los periódicos que dirigió el abogado Eusebio Asquerino y se sucedieron hasta enero de 1844, El Eco de la revolución y $E l 1^{\circ}$ de Setiembre, y con el que, a cargo de Inocencio Riesco Le Grand, La Tarántula, estuvo en la calle desde mediados de septiembre de 1843 y principios de febrero de 1844 . Por lo tanto, se reduce en Madrid el abanico de publicaciones, pero con el éxito de la movilización despareció la coalición periodística, poniéndose fin al hermanamiento y recuperando las posiciones críticas e ideológicas primigenias ${ }^{37}$.

Se retomó la diferencia y la discusión periodística, como la mantenida entre el Eco del Comercio y El Heraldo y sus respectivas interpretaciones, parlamentaria y doctrinaria de la Constitución de 1837. Sin embargo, las principales fuerzas liberales antiesparteristas mantuvieron la alianza y se presentaron juntas a los comicios en una coalición denominada Partido Parlamentario. Además, aunque con su triunfo los elegidos volvieron a sus partidos originales, resultando claramente favorecido el moderado por el número de representantes y por contar muy pronto con el apoyo del grupo centrista Joven España, liderado por Luis González Bravo, persistieron en el acuerdo. Lo hicieron hasta que, una vez proclamada el 8 de noviembre la mayoría de edad de Isabel II e iniciado su reinado efectivo, el primero de sus Gobiernos, el presidido por Salustiano Olózaga, ante la imposibilidad de llevar adelante un programa progresista, el 28 consiguió el decreto de disolución de las Cortes. No fue efectivo porque los moderados, que acariciaban la realidad del poder, actuaron rápidamente y fabricaron un escándalo: el presidente del gabinete había logrado el citado decreto por la fuerza. Corroborado el relato por la reina, Salustiano Olózaga fue exonerado inmediatamente y sustituido por el otrora radical y en este momento ya fervoroso conservador, Luis González Bravo.

37 Para el contexto inmediato al triunfo de la movilización antiesparterista: Francisco Cánovas Sánchez, El partido moderado, op. cit., pp. 7-13 y Carlos Marichal, La revolución liberal y los primeros partidos politicos en España: 1834-1844, op. cit., pp. 254-257. Y para la situación de la prensa madrileña: AVM, Secretaria, 4/163/7 y Eugenio Hartzenbusch, Apuntes para un catálogo de periódicos madrileños desde el año de 1661 a 1870, op. cit., pp. 81-87. 
A partir de entonces, principios de diciembre, se procedió al desmantelamiento de los principales desarrollos legislativos progresistas del régimen constitucional de 1837, muchos de ellos procedentes del doceañismo. Pues bien, para evitar la discusión del anterior escándalo, pero, sobre todo, porque se proponía gobernar en país al margen de las Cortes mediante decretosleyes, a finales de mes se suspendió la legislatura. El objetivo era allanar el camino para la consolidación de los moderados en el poder, mediante la eliminación de las plataformas en las que se habian afirmado los progresistas y las fuerzas a la izquierda. Con tal objeto antes de concluir el año se activó la propuesta conservadora de reforma municipal centralizadora y censitaria de julio de 1840. La importante agitación popular contra esta norma protagonizada por la milicia nacional fue aprovechada para suprimir a esta institución y reemplazarla por un incremento de efectivos del ejército, la reactivación del cuerpo de protección y seguridad en las ciudades y la creación de la policía rural de la guardia civil.

La reforma de la normativa para el ejercicio de la libertad de imprenta, a pesar del importante coro de rotativos conservadores y ministeriales con los que se contaba, la llevó a cabo el ejecutivo una vez que acalló totalmente a la prensa de la oposición. Así ocurrió en Madrid, donde las cabeceras críticas, como hemos visto, eran bastante escasas. Primero, fueron las coacciones, como la que sufrió el Eco del Comercio, cuya redacción el 20 de diciembre fue atacada por un grupo de oficiales, que inutilizaron la prensa, cajas y letras de imprenta, destruyeron la edición del diario del siguiente día y, al no encontrar al director, maltrataron a alguno de sus operarios. Después, fue fundamentalmente la acción gubernativa que se llevó por delante a $E l 1^{\circ}$ de Septiembre, La Tarántula, cuyo director fue detenido, y El Bien del País. Y, por último, la declaración el 6 de febrero de 1844 del estado de excepción que supuso la suspensión del Eco de Comercio y El Espectador hasta el 24 de abril y el 3 de mayo, respectivamente.

Para entonces, desde el 10 de abril, el Gobierno de Luis González Bravo ya habia puesto en vigor, con ligeras alteraciones, el proyecto de ley sobre libertad de imprenta presentado en el Congreso de los Diputados el 27 de mayo de 1840 y lo hizo porque, pese al silencio de la prensa de la oposición, desde que al comienzo del reinado isabelino -señalaba el que fuera redactor de El Guirigay- se "rompieron sin precaución las trabas que encadenaban al pensamiento, se precipitó desenfrenada la prensa por la ancha senda que a su naciente poder abriera la imprevisión de los partidos, la libertad degeneró en licencia, los más respetables objetos fueron blanco de sus imprudentes ataques, se pusieron en cuestión las creencias, las tradiciones, las instituciones del país, se predicó diariamente la sedición (...)". Pues bien, para contener estos excesos, que para el Gobierno las anteriores normas no habian logrado, ésta regulación, entre otros pormenores, incrementaba las exigencias a los editores responsables (que, en el caso de Madrid, suponían el pago de una contribución directa de 1.000 reales y se triplicaba el depósito de una fianza, es decir, 120.000 reales), las penas por los delitos de imprenta, aumentando su cuantía, se reducian exclusivamente a las pecuniarias, se suprimían los jurados de la acusación y se remitían a los tribunales ordinarios los delitos de injurias y calumnias, se cuadriplicaban las cuotas contributivas (2.000 reales en Madrid) y las capacidades exigidas a los jueces de hecho ("No son los proletarios y los ignorantes los que pueden ser jueces en las graves cuestiones que la prensa suscita" -se subrayaba en la 
exposición de motivos), la formación de las listas para los jurados de calificación pasaba al control de la diputación provincial presidida por el jefe político e introducía -como ya señalamos- una doble vía para el control de la prensa, la judicial u ordinaria, a cargo de los promotores fiscales, y la gubernativa o de urgencia, que facultaba a los jefes políticos a suspender la distribución de aquellos impresos que a su juicio pudieran alterar el orden u ofender la moral, debiendo presentar denuncia en las veinticuatro horas siguientes.

En definitiva, nos enfrentamos con una disposición marcadamente gubernativa y muy censitaria, estrechamente vinculada a los grandes propietarios y contribuyentes, a los que los moderados querian reservar el ejercicio de las libertades públicas. Por eso, al igual que los otros desarrollos legislativos planteados por esta formación política bajo el marco del Código político de 1837 y en este momento activados, esta norma se acoplaba mejor con un modelo constitucional más conservador, como el de 1845. De ahí que se mantuviera con él y junto al decreto de 6 de julio de 1845, que sustituía el jurado de la calificación por tribunales especiales de primera instancia, formaran el régimen regulador fundamental del ejercicio de la libertad de imprenta durante la década moderada ${ }^{38}$.

Enviado el (Submission Date): 13/10/2017

Aceptado el (Acceptance Date): 22/12/2017

38 Para el contexto politico: Francisco Cánovas Sánchez, El partido moderado, op. cit., pp. 1338 y Carlos Marichal, La revolución liberal y los primeros partidos politicos en España: 1834-1844, op. cit., pp. 257-262 y 267-271. Y para la evolución de la prensa y los cambios en la normativa: Eco del Comercio, 23.12.1843; Demetrio Castro Alfin, Los males de la imprenta. Politica y libertad de prensa en una sociedad dual, op. cit., pp. 54-56 y Juan Ignacio Marcuello Benedicto, "La libertad de imprenta y su marco legal en la España liberal", op. cit., pp. 75-81. 